\title{
Overcoming Procrastination through Planning
}

\author{
Frank Wieber \& Peter M. Gollwitzer
}

Have you ever purposefully delayed or postponed a goal-directed action (for example, writing an essay or filling out tax forms) despite strong intentions to achieve the goal and sufficient opportunities to pursue it? If so, then you are in good company: so has a large percentage of the general ( 15 to 20 percent) $)^{2}$ and the academic ( 80 to 85 percent of American college students) population. ${ }^{2}$ In addition to academic examples, procrastination has been studied in the areas of personal health (dieting, exercising), social relationships (contacting friends), work (jobseeking behavior), and financial management (retirement savings). ${ }^{3}$ Procrastination is a widespread phenomenon with potentially severe consequences, such as dropping out of school, compromised health, divorce, and job loss.

Intuitively, it would seem relatively easy to classify certain behaviors as procrastination. For example, the fact that a student put off reading a book chapter might at first glance be sufficient to label his or her behavior as procrastination. But after a closer look at the phenomenon, additional criteria that cannot be objectively judged from an outside perspective emerge. Building on the numerous definitions of the commonly used term procrastination that can be found in the scientific literature, ${ }^{4}$ we suggest four criteria that must be fulfilled in order to classify a behavior or a lack of behavior as procrastination. A person has to (1) commit to the goal in question, (2) have the opportunity to act on the goal, (3) expect to be worse off later in the case of a delay, and (4) voluntarily decide to put off the intended action or inaction until a later point. For example, not

1. Harriott and Ferrari, "Prevalence of Chronic Procrastination."

2. Ellis and Knaus, Overcoming Procrastination, 143-149.

3. Akerlof, "Procrastination and Obedience."

4. Van Eerde, "Procrastination"; Ferrari, "Procrastination as Self-Regulation Failure"; Lay and Silverman, "Trait Procrastination." 
reading the chapter would qualify as procrastination by our definition when the student intended to read it, had access to the book and an adequate amount of time to read it, knew that not reading the chapter would endanger the course credit (and ultimately degree fulfillment), and volun tarily decided to read the chapter later. To draw a parallel to the definition set out by Piers Steel, ${ }^{5}$ procrastination is the voluntary postponement of an intended course of action despite having the opportunity to act and expecting to be worse off as a result of the delay.

In light of the high prevalence of procrastination and building on these four criteria, we now address the question of why people procrastinate from the perspective of the psychology of goals. We will analyze the relationship between procrastination and potential problems people may encounter during both goal setting and goal striving. Subsequently, we will suggest a strategy to overcome procrastination: the formation of implementation intentions, which are specific plans detailing when, where, and how one intends to initiate an action that one is prone to put off. 6 After explaining how implementation-intention effects come about and examining several moderators that might limit their effectiveness, we will discuss research on implementation intentions relevant to the problem of procrastination. We will examine whether implementation intentions help people to overcome procrastination in terms of getting started, staying on track, calling a halt to an unsuccessful action, and avoiding overextension. In addition, we will discuss research on the effectiveness of implementation intentions in critical populations (chronic procrastinators and subjects who are known to have problems with self-control), as well as in contexts that do not seem to be amenable to self-regulation, such as when bad habits must be overcome. Finally, we will suggest additional measures to improve motivation as a way of enhancing the effectiveness of implementation intentions.

\section{PROCRASTINATION, GOAL SETTING, AND GOAL STRIVING}

Two sequential tasks have been differentiated by the psychology of goals during goal pursuit: goal setting and goal striving. Traditionally, research on goals has focused on goal setting, aiming to illuminate the factors that determine the formation of strong goal intentions (goal-setting theories), as strong goal intentions were regarded as the proximal determinants of goal achievement. Low perceived desirability and/or feasibility of a

5. Steel, "Nature of Procrastination," 66.

6. Gollwitzer, "Implementation Intentions."

7. Oettingen and Gollwitzer, "Goal Setting and Goal Striving."

8. Ajzen, "Theory of Planned Behavior." 
potential goal as well as suboptimal framing (e.g., unspecific, distal) may lead to the formation of weak intentions to realize the goal and to stbsequent procrastination. One might therefore be tempted to infer that procrastination primarily results from suboptimal goal setting; however, at least two arguments weaken this explanation.

First, numerous research findings demonstrate that even strong goal intentions are not sufficient to guarantee goal achievement (the so-called intention-behavior gap). ${ }^{9}$ Second, procrastinators do not seem to differ from nonprocrastinators in their intention to pursue a goal..$^{10}$ For example, in studies on academic work and job-seeking intentions, procrastination has been found to be unrelated to the strength of goal intentions. "Still, the gap between intentions and goal-directed behavior was found to be greater in procrastinators than in nonprocrastinators. ${ }^{12}$ On the other hand; it was observed that in some cases, goal-setting interventions, such as training sessions or tests, managed to decrease procrastination. ${ }^{13}$ All things considered, strong goal intentions seem to represent an important factor for successful goal achievement. But given the residual intention-behavior gap, the lack of qualitative and quantitative differences between procrastinators' and nonprocrastinators' intentions, and the unreliable effects of goal-setting interventions on procrastination, there must be a more complete explanation for procrastinating behavior beyond merely weak goal intentions.

Goal-setting theories aim to explain the formation of goal intentions but do not address problems that arise when a person tries to realize a set goal. These problems are the focus of self-regulation theories of goal striving, which are concerned with the processes that mediate the effects of intentions on behavior. ${ }^{14}$ In the following section, we will concentrate on four major problems that must be overcome during goal striving: ${ }^{15}$ initiation of action on a goal, staying on track (warding off distractions), disengaging from failing courses of action, and avoiding overextension (ego depletion).${ }^{16}$ We will elaborate on how each of these problems can contribute to procrastination.

The most prominent challenge of successful goal striving is getting started with goal-directed actions; this issue is implicated in the definition of procrastination, ${ }^{17}$ as it is assumed that a procrastinating person is committed to

9. Sheeran, "Intention-Behavior Relations."

10. Steel, "Nature of Procrastination," 79.

11. Lay and Brokenshire, "Conscientiousness."

12. E.g., Steel, Brothen; and Wambach, "Procrastination and Personality."

13. For an overview, see Schouwenburg et al., "Counseling the Procrastinator."

14. E.g., Bandura, Self-Effcacy; Carver and Scheier; "Principles of Self-Regulation"; Gollwitzer, "Implementation Intentions"; Kuhl, "Functional-Design Approach."

15. E.g., Gollwitzer and Sheeran, "Implementation Intentions,"

16. Baumeister et al., "Ego Depletion."

17. Van Eerde, "Procrastination," 374. 
a goal and has the opportunity to act on the goal but avoids the implementation of the intention. The differentiation of two kinds of intention-action discrepancies that has been proposed by research on goals ${ }^{18}$ can also be applied to procrastination. A person may intend to act but does not (an inclined abstainer), or he or she may intend not to act but does so (a disinclined actor). Procrastination in terms of not getting started can refer to not starting to enact a desired goal-directed behavior (e.g., not starting to exercise despite the goal to be physically fit) as well as to the failure to cease an undesired goal-contradictory behavior (e.g., not quitting to smoke despite the goal to stay healthy).

What are reasons for not getting started? Three main explanations have been suggested by research on goal striving: ${ }^{19}$ one fails to remember the intention to act, one does not recognize good opportunities to act, or one does not overcome an initial reluctance to act. Forgetting to act on the intended goal represents a common reason for failure to act (e.g., not remembering to regularly take prescription medication). But although this problem qualifies as a problem of getting started with goal striving, it does not qualify as procrastination, as it fails to meet the criterion of purposefully postponing or delaying an action. Similarly, not recognizing a good opportunity to act on the goal meets the criteria of a problem of goal striving but not of procrastination. However, the third reason, that a person has to overcome an initial reluctance, corresponds with findings on the strong relationship between task aversiveness and procrastination. ${ }^{20}$ Initial reluctance is thought to result from a trade off between attractive long-term consequences and less attractive short-term consequences. For example, a person might strongly intend to eat a low-calorie diet in order to stay healthy in the future, but in the moment of decision, he or she chooses to eat fatty French fries, which are more attractive in the short run than a healthy but less tasty low-fat salad. ${ }^{21}$ In addition to health goals, such trade-off structures can be found in many areas of day-to-day life, such as environmental goals, consumer goals, safer-sex goals, and academic goals.

The second challenge of successful goal striving is avoiding unnecessary disruptions. Most definitions of procrastination refer solely to delaying the start of a goal-directed action. ${ }^{22}$ However, deciding to put off an intended course of action (despite sufficient opportunities to act and expecting to be worse off for the delay) when in the midst of trying to realize a goal also fulfills the above-mentioned criteria of procrastination. For example,

18. E.g., Sheeran, "Intention-Behavior Relations."

19. E.g., Gollwitzer, Gawrilow, and Oettingen, "Power of Planning."

20. For reviews, see Van Eerde, "Meta-Analytically Derived Nomological Network"; Steel, "Nature of Procrastination," 75.

21. See Ainslie, "Specious Reward" and Breakdown of Will, as well as the chapters by Ainslie (chapter 1) and Ross (chapter 2) in this volume.

22. For an overview, see Steel, "Nature of Procrastination," 66. 
a student might start writing an outline of his or her thesis but then become distracted and put off continuing this activity by checking e-mail or surfing the Web. What are the reasons for this kind of procrastination? Research on goal striving suggests that insufficient goal shielding plays an important role in suboptimal regulation of goal-directed responses. ${ }^{23}$ Here, goal shielding refers to the protection of valued goals against other competing influences. When goal striving extends over a long time period, the goal has to be shielded from potentially disruptive stimuli, both internal (e.g., feeling anxious, tired, or overburdened) and external (distractions and temptations).

The third challenge, disengaging on time from fatlty courses of action, also relates to procrastination. An example would be a person who voluntarily postpones necessary updates to his or her investment portfolio, despite having the opportunity to do so and the expectation of reduced gains or increased losses as a result of the delay. Reasons that have been suggested for not disengaging from failing courses of action include the application of a "don't waste" heuristic ${ }^{24}$ (a compulsion to bring an investment to completion) and the motive of self-justification. As the "don't waste" heuristic suggests that no voluntary decision takes place and people may continue to expect positive results in the end, it does not qualify as procrastination. However, the self-justification explanation allows for the possibility that people know that they will most likely be worse off in the long term, yet still voluntarily decide to put off an intended action until a later point, as this allows them to postpone the short-term psychological costs of accepting that their prior resource allocation to the chosen course of action was mistaken. ${ }^{25}$ As a consequence, people may end up throwing good money after bad (the sunk-cost phenomenon).

A final challenge to successful goal striving is avoiding overextending oneself. But how does overextension relate to procrastination? Following the resource model of self-regulation, ${ }^{26}$ the capacity to effortfully regulate one's thoughts, feelings, and actions is limited. When this resource is taxed by excessive use, a state of ego depletion emerges that impairs subsequent self-regulation. For example, after forcing themselves to eat radishes instead of delicious cookies, participants put less effort into solving unsolvable puzzles (decreased persistence). Because counteracting the reasons for procrastination listed above (i.e., overcoming initial reluctance, goal shielding, and overcoming self-justification motives) requires selfcontrol, ego-depleted people ought to be more likely to procrastinate. After depleting one's self-regulatory resources by acting on a goal (for

23. E.g., Achtziger, Gollwitzer, and Sheeran, "Implementation Intentions"; Shah, Friedman, and Kruglanski, "Forgetting All Else."

24. Arkes and Blumer, "Psychology of Sunk Cost."

25. Brockner, "Escalation of Commitment."

26. Baumeister et al., "Ego Depletion." 
example, via thought or emotion suppression), an increased likelihood of procrastination with respect to other goals is to be expected.

In summary, procrastination is not restricted to the postponement of the start of a goal-directed action but can also affect other stages of goal striving, such as the shielding of ongoing goal striving from disruptive internal and external stimuli and the decision to halt a failing course of action. In addition, overextending oneself during goal striving can contribute to procrastination.

\section{ACTION CONTROL BY IMPLEMENTATION INTENTIONS}

What can a person do to overcome procrastination? Several strategies have been suggested, including interventions strengthening the expectation of one's ability to enact the necessary goal-directed actions (selfefficacy); $;^{27}$ changing the value of the task (e.g., piggybacking distant goals onto more immediate goals) ${ }_{i}^{28}$ and reducing sensitivity to distractions through stimulus control (removing temptation cues in one's environment) or automation (habitualizing action control) ${ }^{29}$ In the rest of this chapter, we will propose implementation intentions as an easily applicable planning strategy that can help to overcome procrastination by automating action control.

Implementation intentions support goal intentions. Whereas goal intentions in the format "I intend to achieve outcome X/to perform behavior X" describe desired end states and represent the result of the process of goal setting, implementation intentions additionally spell out in advance when, where, and how these goals should be realized. Implementation intentions have been demonstrated to be especially effective when they are formed in an if-then format (If situation $Y$ arises, then I will perform action $\left.Z^{\prime \prime}\right)$. In the if component of an implementation intention, a concrete situation is specified that is anticipated as a good opportunity to act. In the then component, a proper goal-directed response is included. For example, one could support the goal to finish an essay with the implementation intention "If I turn on my computer, then I will first work 20 minutes on the essay." As a consequence of this predecision, the control over the initiation of the writing behavior is delegated to the specified situation. Starting the computer should automatically activate the linked behavior to work on the essay first without requiring a second conscious decision. The effectiveness of implementation intentions has been demonstrated for all four challenges of goal striving described above (getting

27. Bandura, Self-Efficacy.

28. Ainslie, Picoeconomics.

29. Bargh and Barndollar, "Automaticity in Action." 
started, staying on track, calling a halt, and not overextending oneself). A meta-analysis including 94 studies and more than 8,000 participants ${ }^{30}$ revealed a medium-to-large effect size of implementation intentions on goal achievement over and above the effect of the respective goal intentions alone. ${ }^{31}$ Implementation intentions are an easy strategy to apply, and they have remarkable effects on goal attainment and thus offer an effective countermeasure against procrastination.

How Do Implementation Intentions Improve Goal Attainment?

Two processes have been proposed to explain how implementation intentions improve goal achievement. First, through the if component, they heighten the activation of the critical situation. Second, they automate the initiation of the action specified in the then component in response to the critical situation.

The Specified Situation. Heightened activation of the mental representation of the critical situation helps people to retrieve the specified situation from memory (superior recall) and to detect it even when concealed (perceptual readiness). Similarly, implementation intentions prepare people to attend to critical cues. ${ }^{32}$ In fact, the effects of implementation intentions on attention are so strong that they even disrupt focal attention. ${ }^{33}$ In two studies, the disruption of focal attention through implementation intentions has been tested by presenting stimuli that were part of an implementation intention for an unrelated task as task-irrelevant distractors. In the first study, participants either formed specific implementation intentions in an if-then format or just formed goal intentions. The intentions were directed at the goal of performing well in a subsequent categorization task. Next, participants worked on an ostensibly unrelated task in which they had to make word-versus-nonword decisions while neutral as well as critical stimuli (intention situations) were presented as taskirrelevant distractors. Participants' response times to the word-versusnonword decisions served to measure the disruption of focal attention, such that slower responses indicated more attention disruption by the task-irrelevant distractors. The results revealed that the presence of critical stimuli as distractors slowed down participants' responses compared with the presence of neutral distractor stimuli-but only when participants had formed implementation intentions, not when they had formed goal intentions. In the second study, these findings were replicated using a

30. Gollwitzer and Sheeran, "Implementation Intentions."

31. Webb and Sheeran, "Does Changing Behavioral Intentions."

32. Aarts, Dijksterhuis, and Midden, "To Plan."

33. Wieber and Sassenberg, "I Can't." 
task with vowel-versus-consonant classifications. Moreover, in this study, implementation intentions not only focused attention on critical cues during the unrelated classification task, but they also still improved the detection of the critical cues in the subsequent relevant task. Together, these findings imply that critical cues will not escape a person's attention, given that the relevant goal is activated and that the cues have been included in an implementation intention.

The Goal-Directed Behavior. As a second process, implementation intentions automate the initiation of the action specified in the then component as soon as the critical situation presents itself. To call a behavior automatic, it has to have at least one of several relevant features. ${ }^{34}$ It has been demonstrated that implementation intentions lead to an immediate response to critical stimuli ${ }^{35}$ and to a response without conscious intent, ${ }^{36}$ both characteristic of attomatic behaviors. Furthermore, they enable people to efficiently respond to critical stimuli. To test the efficiency of action initiation through implementation intentions, paradigms were used that required working on two tasks simultaneously (dual-task paradigms). As a person's resources to process information simultaneously are limited, greater efficiency in one subtask in a dual-task paradigm allows the performance of the second subtask to remain constant even as performance of the first improves. In a dual-task study by Brandstätter et al., ${ }^{37}$ participants worked on a primary task in which they had to keep a mousedirected square on top of a moving circle. The secondary task consisted of a go/no go task that required a key press in response to numbers but not to letters appearing at random time intervals in the midst of the moving circle. Prior to working on the dual task, participants either formed an implementation intention to respond as quickly as possible to the number 3 or simply familiarized themselves with the number 3 by writing it down several times. Results indicated that participants who formed an implementation intention responded faster to the critical number 3 than those who only familiarized themselves with this number, and that this was done without impairing the performance in the tracking task. Apparently, implementation intentions forge a strong mental link between the critical cue specified in the if component and the response specified in the then component so that action initiation in the presence of the critical cue becomes automated. It is this automation of the initiation of goal-directed action that should make forming implementation intentions beneficial to overcoming procrastination.

34. E.g., Bargh, "Conditional Automaticity."

35. Gollwitzer and Brandstätter, "Implementation Intentions."

36. Bayer et al., "Responding to Subliminal Cues."

37. Brandstätter, Lengfelder, and Gollwitzer, "Implementation Intentions," studies 3 and 4 . 


\section{Moderators of Implementation-Intention Effects}

In addition to the research on processes underlying implementationintention effects, several studies have investigated the potential limits of the effectiveness of implementation intentions in terms of commitment to their respective goal intentions, commitment to the implementation intention, self-efficacy, and overlap with the personality factors of socially prescribed perfectionism and conscientiousness.

Commitment to the Goal Intention. In accordance with the theory of intentional action control, ${ }^{38}$ empirical research indicates that people need to be strongly committed to their goal intentions in order for implementation-intention effects to occur. ${ }^{39}$ In addition, the activation of the goal intention must be ensured. For example, in a study by Sheeran, Webb, and Gollwitzer, ${ }^{40}$ speed-directed implementation intentions in an if-then format improved participants' response times and thereby their performance only when the goal to respond quickly was activated. Implementation intentions thus produce a kind of goal-dependent automaticity. ${ }^{41}$ But while goal-dependent automaticity typically originates from the frequent and consistent pairing of situations and behaviors (see also proceduralization), ${ }^{42}$ the goal-dependent automaticity of implementation intentions is established by just one conscious act of will. Functionally, the goaldependent automaticity produced by implementation intentions helps prevent rigid action initiation, as it prevents executing implementation intentions in situations in which the goal is not in place. As procrastinators do strongly intend to pursue their goals, ${ }_{f}^{43}$ the requirement of a sufficient commitment of the respective goal intention for implementationintention effects to occur should always be fulfilled.

Commitment to the Implementation Intention. Additionally, the commitment to enacting the implementation intention needs to be strong. For example, in a study by Achtziger, Bayer, and Gollwitzer, ${ }^{44}$ telling participants that they had the type of personality that benefits from staying flexible (low plan commitment) led to weaker implementation-intention effects in comparison to participants told that they had the type of personality that benefits from sticking to plans (high plan commitment). The necessity of commitment to the if-then plan also supports the effectiveness of implementation intentions, by ensuring that incidental or superficial

38. E.g., Gollwitzer and Schaal, "Metacognition in Action."

39. E.g., Verplanken and Faes, "Good Intentions."

40. Sheeran, Webb, and Gollwitzer; "Interplay," study 2.

41. Bargh, "Conditional Automaticity"; Gollwitzer and Schaal, "Metacognition in Action."

42. Anderson, Architeclure of Cognition.

43. E.g. Steel, "Nature of Procrastination," 79.

44. Achtziger, Bayer, and Gollwitzer, "Committting Oneself," study 2. 
if-then plans do not impair flexibility for goal attainment. ${ }^{43}$ Although procrastinators might differ in regard to their planning behavior, it seems plausible that once they form an implementation intention, they commit themselves as strongly to the formed plan as nonprocrastinators do. Indirect support for this notion is provided by research that demonstrates the effectiveness of implementation intentions in procrastinators. ${ }^{46}$ Therefore, the precondition of a strong commitment to the implementation intention should not represent a limitation for implementationintention effects in procrastinators.

Self-Efficacy. A person must be confident that he or she has the ability to perform the actions instrumental to producing the desired outcomes (i.e., he or she must have a high level of selfefficacy $)^{47}$ in order for implementation-intention effects to occur. In an experimental study, we tested the moderation of implementation-intention effects by self-efficacy. ${ }^{48}$ Participants' self-efficacy with respect to taking an abstract reasoning test (Raven matrices) was manipulated before they worked on a set of task trials. To establish low self-efficacy, participants worked on difficult training task trials that mostly led to experiences of failure; to establish high selfefficacy, participants worked on easy training trials that mostly led to mastery experiences. While all participants learned that double-checking their results for each trial was an effective strategy to improve their performance, only in the implementation-intention condition did they formulate this strategy into an if-then plan (If I find an initial solution, then I will double-check it"). A positive effect of implementation intentions was only found in the high-self-efficacy condition; implementation-intention participants in the high-self-efficacy condition took significantly more time to work on the difficult matrices and indeed solved more of them correctly than participants with high self-efficacy who did not include the doublechecking strategy in an implementation intention. For participants with. low self efficacy, implementation intentions neither increased time spent on the difficult matrices nor improved their performance. Low self-efficacy thus limits the effectiveness of implementation intentions. The formation of implementation intentions, on the other hand, cannot be expected to increase self-efficacy ${ }^{\text {t9 }}$ As low self-efficacy is also a strong predictor of procrastination, ${ }^{50}$ it is especially important to ensure that people set realistic goals (not too easy or too hard), so that high self-efficacy to perform the necessary goal-directed actions is probable. Otherwise, forming implementation intentions will not help with overcoming procrastination.

45. E.g. Gollwitzer et al., "Flexible Tenacity."

46. E.g., Owens, Bowman, and Dill, "Overcoming Procrastination."

47. Bandua, Self-Efficacy

48. Wieber, Odenthal, and Gollwitzer, "Self-Efficacy Feelings."

19. Webb and Sheeran, "Mechanisms."

50. Steel, "Nature of Procrastination," 7". 
Personal Attributes. Personal attributes have been examined as moderators of implementation-intention effects in two lines of research. Socially prescribed perfectionism moderated the effectiveness of implementation intentions, ${ }^{51}$ resulting in worse goal achievement among socially prescribed perfectionists. As with self-oriented perfectionism, socially prescribed perfectionism entails setting high personal standards and evaluating oneself stringently, But whereas the standards for self-oriented perfectionists are set by the individuals themselves, socially prescribed perfectionists try to conform to standards and expectations that are prescribed by others. A high level of socially prescribed perfectionism is related to depression, anxiety disorders, and obsessive-compulsive symptoms. ${ }^{52}$

In one study, participants who scored high on the socially prescribed perfectionism subscale of the Multidimensional Perfectionist Scale (MPS) rated their progress on their New Year's resolutions (three personal goals) after two and four weeks lower when they had formed implementation intentions than when they had received control instructions. In a similar second study, participants with high scores on socially prescribed perfectionism who formed implementation intentions not only rated their goal progress lower but also were less satisfied with their personal goal progress and thought that others were less satisfied with their progress (as compared with participants who formed implementation intentions but scored low on this subscale of perfectionism). However, for participants with self-oriented perfectionism, forming implementation intentions actually improved goal progress. A similar result has been found in the meta-analysis on procrastination by $\mathrm{Stee}^{53}$ that revealed a (weak) relationship between socially prescribed perfectionism and procrastination $(r=0.18)$ but no such relationship for self-oriented perfectionism or for perfectionism in general $(r=-0.03)$. Socially prescribed perfectionism not only represents a risk factor for procrastination but also moderates the effectiveness of implementation intentions, such that a high level of this subtype of perfectionism impedes their effectiveness. It seems important, therefore, to find out why socially prescribed perfectionists do not benefit from implementation intentions so that these problems can be circumvented.

A second line of research examined conscientiousness. ${ }^{54}$ In an experimental study using undergraduate students, attendance in class was determined to be a function of conscientiousness, openness to experience, goal intentions, and implementation intentions. Results replicated previous findings that a lack of conscientiousness (low or moderate scores on the conscientiousness subsets of self-control, distractibility, organization, and achievement motivation) generally put people at risk for procrastination,

51. Powers, Koestner, and Topciu, "Implementation Intentions."

S2. E.g., Powers, Zuroff, and Topciu, "Covert and Overt Expressions."

53. Steel, "Nature of Procrastination," 76.

54. Webb, Christian, and Armitage, "Helping Students." 
whereas a high level of conscientiousness represented a protection factor. ${ }^{55}$ While class attendance of highly conscientious students was not changed by forming implementation intentions as it already was at a high level (ceiling effect), low and moderately conscientious students signifcantly benefited from planning when, where, and how they would attend class (increasing their previously low class attendance rates).

In summary, the ability to resist procrastination and the effectiveness of implementation intentions are expected to be strongest when a person is highly committed to the goal (strong goal intentions), believes in his or her ability to enact the action required to produce the desired outcomes (high self-efficacy), and does not have the tendency to evaluate his or her behavior according to high standards set by others (socially prescribed perfectionism). A lack of strong goal intentions, low self-efficacy, and high levels of socially prescribed perfectionism not only are directly associated with procrastination but also limit the effectiveness of implementation intentions. In contrast, while low levels of conscientiousness are also positively associated with procrastination, it is those individuals with low and moderate levels of conscientiousness who especially benefit from implementation intentions to counter procrastination.

\section{EVIDENCE THAT IMPLEMENTATION INTENTIONS HELP OVERCOME PROCRASTINATION}

As the problems of forgetting one's intentions and not recognizing an opportunity to act on one's goals do not qualify as procrastination issues, we will not discuss research on the effectiveness of implementation intentions in overcoming these problems. ${ }^{56}$ Not all studies analyzing goal striving ask participants for their reasons for having delayed action. Therefore, we cannot be entirely sure in these studies whether participants actually procrastinated or, rather, simply pursued other goals that were more important at the time. However, this criticism does not apply to laboratory experiments in which the time to get started on a focal experimental task is assessed. Moreover, participants' goal intentions as well as their goal progress dependent on the implementation-intention manipulation were measured in all reported studies. Although some of these studies used a quasi-experimental approach (classifying groups based on preexisting differences), most studies applied experimental designs (randomly assigning participants to conditions) that allow for causal inferences from the experimental factors to differences in the dependent variables. Two kinds of implementation intentions were used in the presented studies: implementation intentions in an if then format and implementations in

55. Steel, "Nature of Procrastination," 78.

56. E.g., Achtziger, Bayer, and Gollwitzer, "Committing Oneself." 
alternative formats. Although implementation intentions specifying when, where, and how one intends to act on a goal in an if-then format are more effective than implementation intentions without the if-then format, both types of implementation intentions successfully enhance goal attainment. ${ }^{57}$

Procrastination generally occurs as the consequence of a complex interaction of diverse causes. In some cases, it may be driven primarily by situational characteristics or task characteristics. In other cases, personal characteristics might be the predominant factor. In the following sections, we will review studies in accordance to their main focus: as situationrelated, task-related, or individual-related delay.

\section{Getting Started}

As an example of strong situational influences on the postponement of intended actions, a person would be more likely to procrastinate on a goal at times when other important goals or social norms are competing for his or her attention. For instance, in one study, German participants voluntarily committed themselves to the goal of writing an essay on how they spent their Christmas Eve by December 26 (also a holiday in Germany). ${ }^{58}$ To test whether implementation intentions improved participants' goal achievement, half of the sample additionally supported the goal intention with an implementation intention: when, where, and how they intended to write the essay. German Christmas holidays are a time in which any kind of work-related activity is normatively banned in favor of socializing and spending time with family and friends. Thus, participants had to overcome a situational influence (social norms) to pursue their goal. Results revealed that participants who formed implementation intentions were three times more likely to actually write the report (i.e., to procrastinate less) than mere goal-intention participants. They wrote the reports 2.3 days after Christmas, compared with 7.7 days in the control condition, and sent them in 4.9 days after Christmas, compared with 12.6 days in the control condition. Moreover, 71 percent of the participants in the implementation-intention condition sent in their essays, as opposed to 32 percent of those in the control condition. Implementation intentions successfully reduced participants' procrastination even in a situation in which social norms endangered their goal.

Similarly, a person would be expected to be more likely to procrastinate at times when substantial changes are taking place in his or her environment. For example, in a study by Brandstätter et al., ${ }^{59}$ the effect of implementation intentions on getting started in difficult situations was

57. Chapman, Armitage, and Norman, "Comparing Implementation Intention Interventions."

58. Gollwitzer and Brandstätter, "Implementation Intentions," study 2.

59. Brandstätter et al., "Goals Need Implementation Intentions." 
tested in the area of continuing education after the German reunification. Participants were chosen who indicated their interest in continuing education. The interview questions were "What are your plans for the near future with regard to your professional career?" and "Have you ever thought of continuing your education?" To assess whether participants formed an implementation intention, they were asked if they had already committed themselves to when, where, and how they would start to act on the goal to continue their education. Interviews conducted two years later indicated that participants who had formed an implementation intention were more successful in participating in vocational retrainings than those who did not specify when and where they would start to act. Thus, even in times of dramatic change (the first years after reunification), implementation intentions helped the participants to not procrastinate on their goal to continue their education.

Whereas situational factors might have played a primary role in triggering procrastination in the above cases, task-related factors (such as the negative evaluation of actions required to pursue a goal, also called task aversiveness) seem to be mainly responsible for procrastination in other instances. ${ }^{60} \mathrm{~A}$ person might value being physically fit but still put off starting regular physical exercise because he or she simply does not like exercising. Do implementation intentions help people get started even on aversive tasks? Indeed, numerous studies demonstrate the beneficial effects of implementation intentions on getting started even when an initial reluctance to act has to be overcome. ${ }^{61}$ One study on doing weekly math homework (over a period of one month) examined the question of whether implementation intentions specifying the when and how of the intended behavior differed in their effects from implementation intentions using an if-then format. ${ }^{62}$ In this study, participants were provided with computer disks containing a series of tedious arithmetic tasks. Half of the participants formed if-then plans specifying when and how they were planning to act on the goal: "If it is Wednesday at 8:30, then I will perform as many arithmetic tasks as possible." The other half formed implementation intentions detailing when and how by stating: "I will perform as many arithmetic tasks as possible each Wednesday at 8:30."To measure procrastination, the time participants started to work on the arithmetic tasks each week was recorded, and the mean deviation from the intended starting time was computed. When participants formed if-then plans, they deviated 1.5 hours from their intended starting time; in contrast, when the implementation intentions were not in an if-then format, they procrastinated an average of 8.0 hours. Implementation intentions in an if-then format thus helped participants reduce their procrastination behavior on assigned learning goals (performing arithmetic tasks within a certain time

60. Steel, "Nature of Procrastination," 75.

61. Gollwitzer and Sheeran, "Implementation Intentions."

62. Oettingen, Hönig, and Gollwitzer, "Effective Self-Regulation," study 3. 
frame) above and beyond implementation intentions that specify the when and how of the intended behavior not using the if-then format.

Other examples of the effectiveness of implementation intentions in helping people to overcome initial reluctance and get started with aver sive tasks include health goals, such as starting regular physical exercise, conducting breast self-examinations as a cancer-prevention strategy, resuming functional activity after joint-replacement surgery, and eating healthily. Implementation intentions also helped people with their environmental goals, such as using public transport and purchasing organic food, and their professional goals, such as promoting workplace health and safety. ${ }^{63}$ In essence, implementation intentions have been shown to be an efficient self-regulatory strategy to overcome procrastination in many parts of life.

\section{Staying on Track}

A strong predictor of procrastination is insufficient self-control. ${ }^{64}$ An important function of self-control is to ward off potential distractions and temptations during goal striving. We assume that insufficient shielding of one's goals also contributes to procrastination (see above). A classic test for a person's ability to shield an ongoing task from distractions is the resistance-to-temptation paradigm. ${ }^{65}$ In this paradigm, participants work on a tedious task while tempting distractions are presented. Four studies have investigated the effects of implementation intentions on resistance to temptation. In the first three studies, participants worked on a strenuous Concentration Achievement Test, in which arithmetic problems had to be solved while clips of award-winning commercials were simultaneously shown. ${ }^{66}$ Before the task began, various intention conditions were realized. Participants either worked directly on the task (control condition), formed a goal intention to not let themselves get distracted (goalintention condition), or supported this goal intention either with an implementation intention to work harder in the face of distractions (taskfacilitative if-then plan) or with an implementation intention to simply ignore the distraction (temptation-inhibiting if-then plan). Task-facilitative implementation intentions only improved goal achievement when participants' motivation to perform well on the task and to ignore the distractions was low. However, participants who formed temptation-inhibiting implementation intentions outperformed the other groups in all three studies, independent of participants' motivation to perform well on the task and to ignore the distractions.

63. Gollwitzer and Sheeran, "Implementation Intentions."

64. Steel, "Nature of Procrastination," 78.

65. E.g., Patterson and Mischel, "Effects of Temptation-Inhibiting."

66. Gollwitzer and Schaal, "Metacognition in Action." 
In the fourth study, the effectiveness of if-then implementation intentions at shielding goal striving from temptations was tested in six-year-old children. ${ }^{67}$ When children start attending school, it is crucial that they learn to not be easily distracted. To improve goal striving, the strategy to ignore distractions seems to be quite effective. ${ }^{68}$ To test whether even very young children can automate their action control with if-then implementation intentions, children either formed an if-then implementation intention ("If I see a distraction, then I will ignore it") or a control intention ("I will ignore distractions") before attempting to ignore funny cartoon pictures or movie clips while working on a repetitive animal or vehicle categorization task. Reaction times in the categorization task were faster for children who formed if-then implementation intentions, indicating that such intentions helped even six-year-old children to not procrastinate during goal striving.

\section{Disengaging from Bad Means and Goals}

Procrastination can also endanger successful self-regulation after the phase of getting started or staying on track, when the planned course of action is failing and a person needs to disengage but instead stays committed to the goal. The goal may have become a personal rule, which, in turn, may have motivated misperceptions that encourage continuation of a failing course of action, as people may fear that exceptions will undermine their ability to exert self-control when similar situations arise in the future. ${ }^{69}$

But implementation intentions not only may be used to prevent getting derailed from striving smoothly and effectively toward a goal; they can also be used to solve the problem of calling a halt to a faulty goal striving. People often fail to readily relinquish chosen means and goals that turn out to be faulty because of a strong self-justification motive ("I chose this goal or means, so it must be good"). Such escalation phenomena (also referred to as "throwing good money after bad") can be controlled, however, by the use of implementation intentions that specify when and how to consider a switch to a different means or a different goal. For instance, Henderson, Gollwitzer, and Oettingen asked participants who had chosen a certain strategy for a given task goal to form an implementation intention that specified a simple action response ("If I receive disappointing feedback, then l'll switch my strategy") or merely set the goal to always use the best strategy available. ${ }^{70}$ They observed that this implementation intention facilitated disengagement as a response to experienced failure. Interestingly, there was a third condition in which participants specified a complex reflection response in their implementation intention ("If I

67. Wieber et al., "Implementation Intentions Improve Resistance."

68. For an overview, see Metcalfe and Mischel, "A Hot/Cool-System Analysis."

69. Ainslie, Picoeconomics.

70. Henderson, Gollwitzer, and Oettingen, "Implementation Intentions." 
receive disappointing feedback, then I will think about how things have been going with my strategy so far"). In contrast to participants who had specified the simple implementation intention ("then I'll switch my strategy"), those with the more reflective implementation intentions integrated information about recent improvement in forming their relinquishment decision (they were less willing to relinquish their strategy when things were improving). This finding shows that implementation intentions can be used to curb the escalation of behavioral commitment commonly observed when people experience failure with a chosen strategy of goal striving. Using more reflective implementation intentions even allows for flexible relinquishment of a goal-striving strategy in the sense that recent turns to the better are respected in the decision to switch (or not) to a different goal-striving strategy.

\section{Preventing Ego-Depletion Effects}

According to the resource model of self-regulation, ${ }^{71}$ when self-regulatory resources are depleted, performance on stbsequent tasks that tax these resources should be impaired. Two studies have tested whether the automatic nature of the effects of implementation intentions enables people to effectively self-regulate despite depleted self-regulatory resources. In the first study, participants' self-regulatory resources were depleted by having them control their emotions during a humorous movie (the egodepletion condition) or not (the control condition). ${ }^{72}$ Subsequently, they either supported the goal intention to solve as many anagrams as possible with the implementation intention "If I solve an anagram, then I will immediately start to work on the next" or did not, before working on an anagram task. In a replication of the classic ego-depletion effect, participants whose self-regulatory resources were depleted solved fewer anagrams than the two other groups. But, more important, participants who formed implementation intentions solved as many anagrams as participants whose self-regulatory resources were not depleted. Implementation intentions thus enabled participants to successfully strive for their goals even when their self-regulatory resources were depleted.

In the second experimental study, participants either were ego-depleted (from counting down in sevens from 1,000 while standing on the weaker leg) or not (counting to 1,000 in fives while standing normally).$^{73}$ Next, they formed the goal intention to read the ink color of words presented in one of four different colors (Stroop task) as quickly as possible; they either supported this goal intention with the implementation intention "As soon as I see the word, then I will ignore its meaning [e.g., by concentrating on

71. Baumeister et al., "Ego Depletion."

72. Gollwitzer, Bayer, and McCulloch, "Control of the Unwanted."

73. Webb and Sheeran, "Can Implementation Intentions Help." 
the second letter only] and name the ink color it is printed in" or formed no implementation intention. Forming implementation intentions improved the Stroop task performance of participants who had been ego-depleted in the initial task up to the level of the nondepleted control group. Both of these studies support the hypothesis that implementation intentions counteract ego-depletion effects.

\section{Curbing Bad Habits}

As noted above, implementation intentions have been demonstrated to have features of automaticity. Automatic processes are required for successful self-regulation in at least two situations: when no self-regulatory capacities remain for resource-demanding self-regulation (in other words, ego depletion) and to keep other unwanted automatic processes in check. The previously discussed research demonstrates that implementation intentions lead to effective action control even when self-regulatory resources are depleted. The effectiveness of implementation intentions to curb the influence of unwanted automatic responses (bad habits) on the ongoing intended goal striving has also been examined. For example, in a study on recycling behavior, the effectiveness of implementation intentions in replacing well-established habits with new recycling habits was tested. "The recyding behavior of 109 employees of a telecommunications company was observed by measuring the actual amount of paper and the number of plastic cups in their personal wastebaskets before and after an implementation intention manipulation. Over a period of two months, implementation intentions helped participants to overcome their old recycling habits and to recycle as much as a condition in which an eye-catching facility was used to promote paper-recycling behavior and significantly more than control conditions. In addition to situations in which automatic behavioral responses limit goal striving, automatic cognitive responses such as stereotyping and inappropriate automatic emotional responses can also be successfully regulated with implementation intentions. Moreover, implementation intentions were found to improve goal attainment even when intellectual capabilities or competitive opponents limited goal striving. ${ }^{75}$

\section{Attenuating Chronic Problems of Self-Control}

To this point, we have reviewed research in which procrastination was conceptualized as a state procrastination (namely, as a function of the situation or the task or the individual during the pursuit of one goal). But research has also taken into account the stability of individual procrastination

7. Holland, Aarts, and Langendam, "Breaking and Creating Habits."

75. For an overview, see Gollwitzer, Gawrilow, and Oettingen, "Power of Planning." 
behavior, as some people may procrastinate not only occasionally but also chronically. Trait procrastination is characterized by the relatively stable tendency over time to postpone actions that are necessary to reach a goal. ${ }^{76}$

To test the relationship between behavioral intentions and behavioral enactment (the intention-behavior gap) in trait procrastinators and whether implementation intentions would help chronic procrastinators to attend a scheduled experiment at their university, an experiment was conducted with the help of 152 college students. ${ }^{77}$ In a separate first session, participants filled in a questionnaire on their procrastination behavior, to identify self-reported high- or low-level trait procrastinators. Students then received handouts during class about the opportunity to earn extra credit from a study with 10 possible appointment times. Half of the handouts contained instructions to support the goal intention to attend the session with an implementation intention. "You are more likely to keep your appointment if you commit yourself to arriving at the assigned room at one of the times listed above. Select now the time at which you plan to come for the second experiment, write it at the bottom of the second page, and return that page to your instructor:") As a measurement of procrastination, participants' actual attendance at the additional study session was measured. Participants whose self-reports indicated high trait procrastination kept the scheduled appointment less often than those whose self-reports revealed low trait procrastination. In addition to these differences, low as well as high trait procrastinators benefited equally from forming implementation intentions: implementation intentions increased the attendance rates from 8.3 to 51.4 percent in high trait procrastinators and from 27.5 to 71.8 percent in low trait procrastinators. Thus, even people with a chronic tendency to procrastinate benefited from forming implementation intentions as much as low procrastinators did (with 40 percent enhancement).

Implementation intentions have also been found to help other critical samples known to have problems with action control. For example, opiate addicts in withdrawal are known to have problems getting started on their goals. ${ }^{78}$ During opiate withdrawal, people often do not realize their goals, as they are preoccupied with suppressing the automatic and conscious processes that favor the intake of the drugs. It was predicted, however, that even people in withdrawal would benefit from forming implementation intentions. To test this hypothesis, former heroin users at a German hospital were approached during a workshop on how to find and apply for jobs. Patients were asked to voluntarily participate in a study on how young adults master the task of composing a curriculum vitae. At 10:00 A.M.,

76. Schouwenburg, "Procrastination in Academic Settings."

77. Owens, Bowman, and Dill, "Overcoming Procrastination."

78. Brandstätter, Lengfelder, and Gollwitzer, "Implementation Intentions." 
patients were shown a model $\mathrm{CV}$ and then were asked to form the goal to create their own CVs before 5:00 P.M. on the same day. Half of the participants supported this goal with irrelevant implementation intentions: when, where, and how they wanted to have lunch. The other half supported it with goal-directed implementation intentions: when, where, and how they wanted to write their CV. Whereas irrelevant implementation intentions did not help participants under withdrawal to realize this goal (none of the 10 participants in this condition handed in a CV at 5:00 P.M.), goal-directed implementation intentions did (eight of the participants in this condition handed in a CV at 5:00 P.M.). When using relevant implementation intentions, people procrastinate less, even when suffering from conditions of high cognitive load (in this study, being occupied by controlling the urge to use drugs).

In line with these findings, people suffering from schizophrenia and patients with frontal-lobe injuries were found to perform well on difficult executive-function tasks (e.g., go/no go tasks) when using implementation intentions. ${ }^{79}$ In addition, children with attention-deficit/hyperactivity disorder (ADHD) benefited from forming implementation intentions in executive-function tasks (e.g., Stroop task) as well as in more real-life self-control tasks (e.g., delay-of-gratification paradigm). ${ }^{80}$

\section{CONCLUSION}

Procrastination, understood as the voluntary delay of an intended course of action despite having the opportunity to act and expecting to be worse off for the delay, is a widespread phenomenon. Whereas previous research discussed procrastination mainly in relation to the failure to get started, we extend this notion to all stages of goal striving. People might not get started to act on an intended goal, might not continue pursuing a goal, might not disengage from goal intentions that became unattainable, or might procrastinate after overextending themselves (in the case of ego depletion). To fight procrastination, implementation intentions are suggested as an easily applicable self-regulatory strategy. Implementation intentions refer to specific plans in which people specify when, where, and how they intend to pursue a goal, preferably in the form of an if-then plan. Research shows that implementation intentions help people overcome procrastination with respect to various problems of goal striving, improve goal attainment in situations where goal striving is handicapped (e.g., by bad habits, lack of skills, or competitors), and even improve results in populations known to have chronic problems of action control.

79. Brandstätter, Lengfelder, and Gollwitzer, "Implementation Intentions, study 2; Lengfelder and Collwitzer, "Reflective and Reflexive Action Control."

80. Gollwitzer, Gawrilow, and Oettingen, "Power of Planning." 
An important precondition for implementation-intention effects to occur is that strong goal intentions are in place. Future research should therefore develop implementation-intention interventions that are backed up by interventions geared at creating strong goal intentions. For example, protection-motivation interventions ${ }^{81}$ or the goal-setting strategy of mental contrasting could precede the formation of implementation intentions as a reinforcement strategy. In a longitudinal study on exercising, ${ }^{82}$ participants not only formed self-set implementation intentions-determining when, where, and how they planned to overcome an obstacle; deciding how to prevent an obstacle from occurring; and specifying a good opportunity to act-but also first elaborated positive outcomes of regular exercising and contrasted them with possible obstacles (engaged in mental contrasting). An increase in exercising was observed as an immediate consequence of this intervention; more impressively, this increase held up over the extensive time period of two years. This line of research is most promising, and we hope it continues to highlight the efficacy of implementation intentions, especially as they relate to procrastination.

\section{ACKNOWLEDGMENTS}

We would like to thank Chrisoula Andreou and Mark White for organizing the CSMN workshop and editing this volume. The inspiring discussions at the workshop helped us to pinpoint the thief of time from an interdisciplinary perspective and to thereby advance our understanding of how procrastination might be curbed by implementation intentions. We are also grateful to Olav Gjelsvik and Jennifer Hornsby, as well as the Centre for the Study of Mind in Nature for sponsoring the CSMN workshop. 


\section{Bibliography}

Aarts, Henk, Ap Dijksterhuis, and Cees Midden. "To Plan or Not to Plan? Goal Achievement of Interrupting the Performance of Mundane Behaviors." European Journal of Social Psychology 29 (1999): 971-979.

Achtziger, Anja, Ute C. Bayer, and Peter M. Gollwitzer. "Committing Oneself to Implementation Intentions: Attention and Memory Effects for Selected Situational Cues." Unpublished manuscript.

Achtziger, Anja, Peter M. Gollwitzer, and Paschal Sheeran. "Implementation Intentions and Shielding Goal Striving from Unwanted Thoughts and Feelings." Personality and Social Psychology Bulletin 34 (2008): 381-393.

Adams, Henry. The Education of Henry Adams. Ed. by Enest Samuels. Boston: Houghton Mifflin, 1973.

Ainslie, George. Breakdown of Will. Cambridge: Cambridge University Press, 2001.

- "Can Thought Experiments Prove Anything about the Will?" In Distributed Cognition and the Will: Individual Volition and Social Context, ed. by Don Ross, David Spurrett, Harold Kincaid, and G. Lynn Stephens, 169-196. Cambridge, Mass.: MIT Press, 2007.

- . "The Dangers of Willpower: A Picoeconomic Understanding of Addiction and Dissociation." In Getting Hooked: Rationality and Addiction, ed. by Jon Elster and Ole-Jørgen Skog, 65-92. Cambridge: Cambridge University Press, 1999.

- "Hyperbolic Discounting versus Conditioning and Framing as the Core Process in Addictions and Other Impulses." In What Is Addiction? ed. by Don Ross, Harold Kincaid, David Spurrett, and Peter Collins. Cambridge, Mass: MIT Press, forthcoming.

- "Impulse Control in Pigeons." Yournal of the Experimental Analysis of Behavior 21 (1974): 485-489.

_- "Motivation Must Be Momentary." In Understanding Choice, Explaining Behaviour: Essays in Honor of Ole-Jørgen Skog, ed. by Jon Elster, Olav Gjelsvik, Aanund Hylland, and Karl Moene, 9-24. Oslo: Unipub Forlag/Oslo Academic Press, 2006.

- Picoeconomics: The Strategic Interaction of Successive Motivational States within the Person. Cambridge: Cambridge University Press, 1992.

-. "Pleasure and Aversion: Challenging the Conventional Dichotomy." Inquiry, 52 (2009): 357-377.

- "Précis of Breakdown of Will." Behavioral and Brain Sciences 28 (2005): $635-673$.

- "Specious Reward: A Behavioral Theory of Impulsiveness and Impulse Control." Psychological Bulletin 82 (1975): 463-496. 
Ainslie, George, and John Monterosso. "Building Blocks of Self-Control: Increased Tolerance for Delay with Bundled Rewards." Journal of the Experimental Analysis of Behavior 79 (2003): 83-94.

Ajzen, Icek. "The Theory of Planned Behavior." Organizational Behavior and Human Decision Processes 50 (1991): 179-211.

Akerlof; George. "Procrastination and Obedience." American Economic Review 81, no. 2 (1991): 1-19.

Allen, David. Getting Things Done: The Art of Stress-Free Productivity. New York: Penguin, 2001.

Andersen, Steffan, Glenn Harrison, Morten Lau, and E. Elisabet Rutstrom. "Eliciting Risk and Time Preferences." Econometrica 76 (2008): 583-618.

Anderson, Joel. "Autonomielücken als soziale Pathologie. Ideologiekritik jenseits des Paternalismus" ["Autonomy Gaps as Social Pathology: Ideologiekritik without Paternalism"], trans. R. Celikates and E. Engels. In Sozialphilosophie und Kritik, ed. by Rainer Forst, Martin Hartmann, Rahel Jaeggi, and Martin Saar, 433-453. Frankfurt: Suhrkamp, 2009.

Anderson, John R. The Architecture of Cognition. Cambridge, Mass.: Marvard University Press, 1983.

Andreou, Chrisoula. "Environmental Damage and the Puzzle of the Self-Torturer." Philosophy and Public Affairs 34 (2006): 95-108.

_. "Environmental Preservation and Second-Order Procrastination." Philosophy and Public Affairs 35 (2007): 233-248.

. "Going from Bad (or Not So Bad) to Worse: On Harmful Addictions and Habits." American Philosophical Quarterly 42 (2005): 323-31.

- "Instrumentally Rational Myopic Planning." Philosophical Papers 33 (2004): $133-145$.

- "Making a Clean Break: Addiction and Ulysses Contracts." Bioethics 22 (2008): 25-31.

- "Temptation and Deliberation." Philosophical Studies 131 (2006): 583-606.

- "Understanding Procrastination." Journal for the Theory of Social Behaviour 37 (2007): 183-193.

Annas, Julia. The Morality of Happiness. New York: Oxford University Press, 1995.

Anscombe, G. E. M. Intention, 2nd ed. Ithaca, N.Y.: Cornell University Press, 1985.

- "Modern Moral Philosophy." In Virtue Ethics, ed. by Roger Crisp and Michael Slote, 26-44. Oxford: Oxford University Press, 1997.

Ariely, Dan. Predictably Irrational: The Hidden Forces That Shape Our Decisions. New York: HarperCollins, 2008.

Ariely, Dan, and Klaus Wertenbroch. "Procrastination, Deadlines, and Performance: Self-Control by Pre-Commitment." Psychological Science 13 (2002): 219-224.

Aristotle. Nicomachean Ethics. Trans. by David Ross. Oxford: Oxford University Press, 1998.

Arkes, Hal R., and Catherine Blumer. "The Psychology of Sunk Cost." Organizational Behavior and Yuman Decision Processes 35 (1985): 124-140.

Arpaly, Nomi. "On Acting Rationally against One's Best Judgment." Ethics 110 (2000): 488-513.

Arvey, Richard D., Maria Rotundo, Wendy Johnson, Zhen Zhang, and Matt McGue. "The Determinants of Leadership Role Occupancy: Genetic and Personality Factors." Leadership Quarterly 17 (2006): 1-20. 
Asheim, Geir B. "Procrastination, Partial Naiveté, and Behavioral Welfare Analysis." Memorandum 02/2007, Department of Economics, University of Oslo, revised August 2008. Available at http://folk uio.no/gasheim/procra02.pdf [accessed August 17, 2009).

Audi, Robert. "Weakness of Will and Rational Action." Australasian Journal of Philosophy 68 (1990): 270-281.

Augustine. The Confessions of Saint Augustine. Trans. by Edward B. Pusey. New York: Random House, 1949.

Bacharach, Michael. Beyond Individual Choice. Princeton: Princeton University Press, 2006.

Bain, Alexander. The Emotions and the Will. New York: Appleton, 1859/1886.

Bandura, Albert. Self-Efficacy: The Exercise of Control. New York: Freeman, 1997.

Bargh, John A. "Conditional Automaticity: Varieties of Automatic Influence in Social Perception and Cognition." In Unintended Thought, ed. by James Uleman and John A. Bargh, 3-51. New York: Guilford, 1989.

Bargh, John A., and Kimberly Barndollax. "Automaticity in Action: The Unconscious as Repository of Chronic Goals and Motives." In The Psychology of Action: Linking Cognition and Motivation to Behavior, ed by Peter M. Gollwitzer and John A. Bargh, 457-481. New York: Guilford, 1996.

Bargh, John A, and Tanya L. Chartrand. "The Unbearable Automaticity of Being." American Psychologist 54 (1999): 467-468.

Baumeister, Roy F, Ellen Bratslavsky, Mark Muraven, and Dianne M. Tice. "Ego Depletion: Is the Active Self a Limited Resource?" Youmal of Personality and Social Psychology 74 (1998): 1252-1265.

Baumeister, Roy F, and Todd Heatherton. "Self-Regulation Failure: An Overview." Psychological Inquiry 7 (1996): 1-15.

Baumeister, Roy F., Todd Heatherton, and Dianne M. Tice. Losing Control. Burlington, Mass.: Academic Press, 1994.

Baumeister, Roy F, and Kathleen Vohs, eds. Handbook of Self-Regulation: Research, Theory and Applications. New York: Guilford, 2007.

Bayer, Ute C., Anja Achtziger, Peter M. Gollwitzer, and Gordon Moskowitz. "Responding to Subliminal Cues: Do If-Then Plans Cause Action Preparation and Initiation without Conscious Intent?" Social Cognition 27 (2009): 183-201.

Becerra, Lino, Hans C. Breiter, Roy Wise, R. Gilberto Gonzalez, and David Borsook. "Reward Circuitry Activation by Noxious Thermal Stimuli." Neuron 32 (2001): 927 m.m.

Beck, Ulrich. Risk Society: Towards a New Modernity. London: Sage, 1992.

Becker, Gary S. "Crime and Punishment: An Economic Approach." Journal of Political Economy 76 (1968): 169-217.

Becker, Gary S., and Kevin Murphy. "A Theory of Rational Addiction." Journal of Political Economy 96 (1988): 675-700.

Becker, Howard S. "Notes on the Concept of Commitment." American Journal of Sociology 66 (1960): 32-40.

Bénabou, Roland, and Jean Tirole. "Willpower and Personal Rules." Journal of Political Economy 112 (2004): 848-886.

Benhabib, Jess, and Alberto Bisin. "Modeling Internal Commitment Mechanisms and Self-Control: A Neuroeconomics Approach to Consumption-Saving Decisions." Games and Economic Behavior 52 (2004): 460-492.

Bernheim, B. Douglas, and Antonio Rangel. "Addiction and Cue-Triggered Decision Processes." American Economic Review 94 (2004): 1558-1590. 
Berns, Gregory S., C. Monica Capra, and Charles Noussair. "Receptor Theory and Biological Constraints on Value." Annals of the New York Academy of Sciences 1104 (2007): 301-309.

Berridge, Kent C. "Motivation Concepts in Behavioral Neuroscience." Physiology and Behavior 81 (2004): 179-209.

Bickel, Warren K, and Matthew W. Johnson. "Delay Discounting: A Fundamental Behavioral Process of Drug Dependence." In Time and Decision: Economic and Psychological Perspectives on Intertemporal Choice, ed. by George Loewenstein, Daniel Read, and Roy F. Baumeister, 419-440. New York: Russell Sage Foundation, 2003.

Boice, Robert. "Quick Starters: New Faculty Who Succeed." New Directions for Teaching and Learning 48 (1991): 111-121.

Boice, Robert. Procrastination and Blocking: A Novel, Practical Approach. Westport, Conn.: Praeger, 1996

Brandstätter, Veronika, Dörte Heimbeck, Juliane T. Malzacher, and Michael Frese. "Goals Need Implementation Intentions: The Model of Action Phases Tested in the Applied Setting of Continuing Education." European Journal of Work and Organizational Psychology 12 (2003): 37-59.

Brandstätter, Veronika, Angelika Lengfelder, and Peter M. Gollwitzer. "Implementation Intentions and Efficient Action Initiation." Journal of Personality and Social Psychology 81 (2001): 946-960.

Bratman, Michael E. Faces of Intention: Selected Essays on Intention and Agency. Cambridge: Cambridge University Press, 1999.

-Intention, Plans, and Practical Reason. Cambridge, Mass.: Harvard University Press, 1987.

- "Planning and Temptation." In Faces of Intention: Selected Essays on Intention and Agency, 35-57. Cambridge: Cambridge University Press, 1999.

_. "Temptation Revisited." In Structures of Agency: Essays, 257-282. Oxford: Oxford University Press, 2007.

Brennan, Timothy J. "Voluntary Exchange and Economic Claims." Research in the History of Economic Thought and Methodology 7 (1990): 105-124.

Brockner, Joel. "The Escalation of Commitment to a Failing Course of Action: Toward Theoretical Progress." Academy of Management Review 17 (1992): 39-61.

Broome, John. "Does Rationality Consist in Responding Correctly to Reasons?" Journal of Moral Philosophy 4 (2007): 349-374.

- Ethics out of Economics. Cambridge: Cambridge University Press, 1999.

_. "Reasoning with Preferences?" In Preferences and Well-Being, ed. by Serena Olsaretti, 183-208. Cambridge: Cambridge University Press, 2006.

Bruner, Jerome. Acts of Meaning: Four Lectures on Mind and Culture. Cambridge, Mass: Harvard University Press, 1992.

Buehler, Roger, Dale Griffin, and Michael Ross. "Exploring the Planning Fallacy." Joumal of Personality and Social Psychology 67 (1994): 366-81.

Burge, Tyler. "Individualism and the Mental." Midwest Studies in Philosophy 4 (1979): 73-121.

Burka, Jane B., and Lenora M. Yuen. Procrastination: Why You Do lt, What to Do about It. Cambridge, Mass.: Da Capo, 1990.

Butler, Joseph. "Of Personal Identity." In Personal Identity, ed. by John Perry, 99-105. Berkeley: University of California Press, 1975. 
Carroll, Lewis. Through the Looking Glass. In Complete Works, 131-272. New York: Vintage/Random House, 1976.

Carver, Charles S., and Michael Scheier. "Principles of Self-Regulation: Action and Emotion." In Handbook of Motivation and Cognition: Foundations of Social Behavior, Vol. 2, ed. by E. Tory Higgins and Richard M. Sorrentino, 3-52. New York: Guilford, 1990.

Chapman, Janine, Christopher J. Armitage, and Paul Norman. "Comparing Implementation Intention Interventions in Relation to Young Adults' Intake of Fruit and Vegetables." Psychology and Health 24 (2009): 31 7-332.

Christensen-Szalanski, Jay. "Discount Functions and the Measurement of Patients" Values: Women's Decisions during Childbirth." Medical Decision Making 4 (1984): 47-58.

Cicero. Philippics. Trans. by Walter C. A. Ker. Suffolk, U.K.: St. Edmundsbury, 1926.

Clark, Andy. Being There: Putting Brain, Body, and World Together Again. Cambridge, Mass.: MIT Press, 1997.

Conti, Regina. "Competing Demands and Complimentary [sic] Motives: Procrastination on Intrinsically and Extrinsically Motivated Projects." Joumal of Social Behavior and Personality 15, no. 5 (2000): 47-60.

Cooter, Robert D. "Lapses, Conflict, and Akrasia in Torts and Crimes: Towards an Economic Theory of the Will." International Review of Law and Economics 11 (1991): 149-164.

Damasio, Antonio. Descartes' Error. New York: Putnam, 1994.

Davidson, Donald. Essays on Actions and Events. Oxford: Clarendon Press, 1980.

- How Is Weakness of the Will Possible?" In Essays on Actions and Events, 21-42. Oxford: Clarendon Press, 1980.

- "Intending." In Essays on Actions and Events, 83-102. Oxford: Clarendon Press, 1980.

Delaney, Liam, Carolyn Rawdon, Kevin Denny, Wen Zhang, and Richard Roche. "Event-Related Potentials Reveal Differential Brain Regions Implicated in Discounting in Two Tasks." Working Paper 200811, Geary Institute, University College Dublin. Available at http://ideas.repec.org/p/ucd/wpaper/200811. html.

Deluty, Martin Z. "Self-Control and Impulsiveness involving Aversive Events." Joumal of Experimental Psychology: Animal Behavior Processes 4 (1978): 250266.

Deluty, Martin Z., Wayne G. Whitehouse, Mark Millitz, and Phillip N. Hineline. "Self-Control and Commitment involving Aversive Events." Behavior Analysis Letters 3 (1983): 213-219.

Dennett, Daniel. Consciousness Explained. Boston: Little, Brown, 1991.

-Why You Can't Make a Computer That Feels Pain." In Brainstorms: Philosophical Essays on Mind and Psychology, 190-229. Cambridge, Mass.: Bradford, 1978.

Dijksterhuis, Ap, and John A. Bargh. "The Perceptual-Behavior Expressway: Automatic Effects of Social Perception and Social Behavior." In Advances in Experimental Social Psychology, Vol. 30, ed. by M. Zanna, 1-40. New York: Academic Press, 2001.

Dodd, Dylan. "Weakness of Will as Intention-Violation." European Journal of Philosophy 17 (2009): 45-59. 
Doris, John M. Lack of Character: Personality and Moral Behavior. Cambridge: Cambridge University Press, 2002.

Dreier, James. "Humean Doubts about Categorical Imperatives." In Varieties of Practical Reasoning, ed. by Elijah Millgram, 27-47. Cambridge, Mass.: MIT Press, 2001.

Dweck, Carol. "Motivational Processes Affect Learning," American Psychologist 41 (1986): 1040-1048.

Edwards, Jonathan. "Procrastination or the Sin and Folly of Depending on Future Time." Available at http:/www.biblebb.com/files/edwards/procrastination. htm (accessed February 28, 2009).

Ellis, Albert, and Williams J. Knaus. Overcoming Procrastination. New York: Signet, 1977.

Elster, Jon. Alchemies of the Mind: Rationality and the Emotions. Cambridge: Cambridge University Press, 1999.

- Explaining Social Behavior. Cambridge: Cambridge University Press, 2007.

Solomonic Judgements: Studies in the Limitations of Rationality. Cambridge: Cambridge University Press, 1989.

- Ulysses and the Sirens: Studies in Rationality and Irrationality. Cambridge: Cambridge University Press, 1984.

-_._.. Ulysses Unbound: Studies in Rationality, Precommitment, and Constraints. Cambridge: Cambridge University Press, 2000.

- "Urgency." Inquiry 52 (2009): 399-411.

-.... "Weakness of Will and Preference Reversals." In Understanding Choice, Explaining Behaviour: Essays in Honor of Ole-Jørgen Skog, ed. by Jon Elster, Olav Gjelsvik, Aanund Hylland, and Karl Moene, 57-73. Oslo: Unipub Forlag/Oslo Academic Press, 2006.

Engle, Randall. "What Is Working Memory Capacity?" In The Nature of Remembering: Essays in Honor of Robert G. Crowder, ed. by Henry Roediger III and James Nairne, 297-314. Washington, D.C.: American Psychological Association, 2001.

Engstrom, Stephen. "The Inner Freedom of Virtue." In Kant's Metaphysics of Morals: Interpretative Essays, ed. by Mark Timmons, 289-315. Oxford: Oxford University Press, 2002.

Epictetus. Handbook of Epictetus. Trans. by Nicholas White. Indianapolis: Hackett, 1983.

Epicurus. "Letter to Menoeceus 121-135." In Voices of Ancient Philosophy: An Introductory Reader, ed. by Julia Annas, 338-340. New York: Oxford University Press, 2000.

Ferrari, Joseph R. "Procrastination as Self-Regulation Failure of Performance: Effects of Cognitive Load, Self-Awareness, and Time Limits on 'Working Best under Pressure." European Journal of Personality 15 (2001): 391-406.

Ferrari, Joseph R., and John F. Dovidio. "Examining Behavioral Processes in Indecision: Decisional Procrastination and Decision-Making Style."Joumal of Research in Personality 34 (2000): 127-137.

Ferrari, Joseph R., Judith L. Johnson, and William G. McCowen. Procrastination and Task Avoidance: Theory, Research, and Treatment. New York: Springer, 1995.

Ferrari, Joseph R., and T. Patel. "Social Comparisons by Procrastinators: Rating Peers with Similar or Dissimilar Delay Tendencies." Personality and Individual Differences 37 (2004): 1493-1501. 
Ferrari, Joseph R, and Timothy Pychyl, eds. Procrastination: Current Issues and New Directions. Corte Madera, Calif: Select, 2000.

Fischer, Carolyn. "Read This Paper Even Later: Procrastination with TimeInconsistent Preferences." Working paper. 1999. Available at http://www.rfforg/ documents/RFF-DP-99-19.pdf.

- "Read This Paper Later: Procrastination with Time-Consistent Preferences." Joumal of Economic Behavior and Organization 46 (2001): 249-69.

Franklin, Benjamin. Autobiography. New Haven, Conn.: Yale University Press, 1976. Frederick, Shane, George Loewenstein, and Ted O'Donoghue. "Time Discounting and Time Preference: A Critical Review." In Advances in Behavioral Economics, ed. by Colin F. Camerer, George Loewenstein, and Matthew Rabin, 162-222. New York: Russell Sage Foundation, 2004.

Fried, Charles. Contract as Promise: A Theory of Contractual Obligation. Cambridge, Mass: Harvard University Press, 1981.

Fudenberg, Drew, and David Levine. "A Dual Self Model of Impulse Control." Harvard Institute of Economic Research, Discussion Paper No. 2112. Available at http://papers.ssrn.com/sol3/papers.cfm?abstract_id $=888752$.

Gailliot, Matthew T., Roy F. Baumeister, C. Nathan DeWall, Jon K. Maner, E. Ashby Plant, Dianne M. Tice, Lauren E. Brewer, and Brandon J. Schmeichel. "Self-Control Relies on Glucose as a Limited Energy Source: Willpower Is More Than a Metaphor." Joumal of Personality and Social Psychology 92 (2007): 325-336.

Garner, D. M., and S. C. Wooley. "Confronting the Failure of Behavioral and Dietary Treatments of Obesity." Clinical Psychology Review 11 (1991): 729-780.

Garvey, Andrew J., Taru Kinnunen, Zandra N. Quiles, and Pantel S. Vokonas. "Smoking Cessation Patterns in Adult Males Followed for 35 Years." Poster presented at Society for Research on Nicotine and Tobacco Annual Meetings, Savannah, Ga., 2002 (http://www.hsdm.harvard.edu/pdf-files/Dr._Garvey.pdf).

Gauthier, David. "Resolute Choice and Rational Deliberation: A Critique and Defense." Nous 31 (1997): 1-25.

Gibbon, John. "Scalar Expectancy Theory and Weber's Law in Animal Timing." Psychological Review 84 (1977): 279-325.

Gilbert, Daniel T, and Jane E. J. Ebert. "Decisions and Revisions: The Affective Forecasting of Changeable Outcomes." Joumal of Personality and Social Psychology 82 (2002): 503-514.

Gjelsvik, Olav. "Are There Reasons to Be Rational?" In Homage à Wlodek: Philosophical Papers Dedicated to Wlodek Rabinowicz, ed. by T. Rønnow-Rasmussen, B. Petersson, J. Josefsson, and D. Egonsson. 2007. Available at http://wrww.fil. lu.se/hommageawlodek.

Glimcher, Paul, Joe Kable, and Kenway Louie. "Neuroeconomic Studies of Impulsivity: Now or Just as Soon as Possible?" American Economic Review 97(2) (2007): 142-147.

Gollwitzer, Peter M. "Implementation Intentions: Strong Effects of Simple Plans." American Psychologist 54 (1999): 493-503.

Gollwitzer, Peter M., Ute Bayer, and Kathleen McCulloch. "The Control of the Unwanted." In The New Unconscious, ed. by Ran R. Hassin, James S. Uleman, and John A. Bargh, 485-515. Oxford: Oxford University Press, 2005.

Gollwitzer, Peter M., and Veronika Brandstätter. "Implementation Intentions and Effective Goal Pursuit." Joumal of Personality and Social Psychology 73 (1997): $186-199$. 
Gollwitzer, Peter M., Caterina Gawrilow, and Gabriele Oettingen. "The Power of Planning: Effective Self-Regulation of Goal Striving." In From Society to Brain: The New Sciences of Self Control, ed. by Ran R. Hassin, Kevin N. Ochsner, and Yaacov Trope. Oxford: Oxford University Press, forthcoming.

Gollwitzer, Peter M., Elisabeth J. Parks-Stamm, Alexander Jaudas, and Paschal Sheeran. "Flexible Tenacity in Goal Pursuit." In Handbook of Motivation Science, ed. by James Y. Shah and Wendi L. Gardner, 325-341. New York: Guilford, 2008.

Gollwitzer, Peter M., and Bernd Schaal. "Metacognition in Action: The Importance of Implementation Intentions." Personality and Social Psychology Review 2 (1998): 124-136.

Gollwitzer, Peter M., and Paschal Sheeran. "Implementation Intentions and Goal Achievement: A Meta-Analysis of Effects and Processes." Advances in Experimental Social Psychology 38 (2006): 69-119.

Goncharov, Ivan. Oblomov. New York: Penguin, 1978.

Green, Leonard, and Joel Myerson. "A Discounting Framework for Choice with Delayed and Probabilistic Rewards." Psychological Bulletin 130 (2004): $769-792$.

Gregor, Mary. Laws of Freedom. Oxford: Basil Blackwell, 1963.

Griffin, James. Well-Being. Oxford: Oxford University Press, 1988.

Gul, Farouk, and Wolfgang Pesendorfer. "The Simple Theory of Temptation and Self-Control." Working paper. Available at http://www.princeton.edu/ pesendor/finite.pdf

-... "Temptation and Self-Control." Econometrica 69 (2001): 1403-1436.

Guyer, Paul. Kant on Freedom, Law, and Happiness. Cambridge: Cambridge University Press, 2000.

Habermas, Jürgen. "Individuation through Socialization: On George Herbert Mead's Theory of Subjectivity." In Postmetaphysical Thinking: Between. Metaphysics and the Critique of Reason, 149-204. Cambridge, U.K.: Polity, 1994.

Hall, Brandon L., and Daniel E. Hursch. "An Evaluation of the Effects of a Time Management Training Program on Work Efficiency." Journal of Organizational Behavior Management 3 (1982): 73-96.

Hardin, Russell. Collective Action. Baltimore: Johns Hopkins University Press, 1982.

Hariri, Ahmed, Sarah Brown, Douglas Williamson, Janine Flory, Harriet de Wit, and Stephen Manuck. "Preference for Immediate over Delayed Rewards Is Associated with Magnitude of Ventral Striatal Activity." Joumal of Neuroscience 26 (2006): 13213-13217.

Harriott, Jesse, and Joseph R. Ferrari. "Prevalence of Chronic Procrastination among Samples of Adults." Psychological Reports 73 (1996): 873-877.

Heath, Joseph. Following the Rules. New York: Oxford University Press, 2008.

Heatherton, Todd F, and Roy F. Baumeister. "Self-Regulation Failure: Past, Present, and Future." Psychological Inquiry 7 (1996): 90-98.

Helzer, John E., Audrey Burnham, and Lawrence T. McEvoy. "Alcohol Abuse and Dependence." In Psychiatric Disorders in America: The Epidemiologic Catchment Area Study, edited by Lee N. Robins and Darrel A. Regier, 81-115. New York: Free Press, 1991.

Henderson, Marlone D., Peter M. Gollwitzer, and Gabriele Oettingen. "Implementation Intentions and Disengagement from a Failing Course of Action." Journal of Behavioral Decision Making 20 (2007): 81-102. 
Hernstein, Richard J. "The Evolution of Behaviorism." American Psychologist 32 (1977): 593-603.

- The Matching Law. Cambridge, Mass.: Harvard University Press, 1997. . "Melioration as Behavioral Dynamism." In Quantitative Analyses of Behavior, Volume II: Matching and Maximizing Accounts, ed. by Michael Commons, Richard J. Herrnstein, and Howard Rachlin, 433-458. Cambridge, Mass.: Ballinger, 1982.

- "Relative and Absolute Strength of Response as a Function of Frequency of Reinforcement." Journal of the Experimental Analysis of Behavior 4 (1961): $267-272$.

Herrnstein, Richard J., and Drazen Prelec. "A Theory of Addiction." In Choice over Time, ed. by George Loewenstein and Jon Elster, 331-361. New York: Russell Sage Foundation, 1992.

Heylighen, Francis, and Clément Vidal. "Getting Things Done: The Science behind Stress-Free Productivity." Long Range Planning 41 (2008): 585-605.

Hill, Thomas E. "Weakness of Will and Character." In Autonomy and Self-Respect, 118-137. Cambridge: Cambridge University Press, 1991.

Hoch, Stephen, and George Loewenstein. "Time-Inconsistent Preferences and Consumer Self-Control." Journal of Consumer Research 17 (1991): 492-507.

Holland, Rob W., Henk Aarts, and Daan Langendam. "Breaking and Creating Habits on the Work Floor: A Field Experiment on the Power of Implementation Intentions." Joumal of Experimental Social Psychology 42 (2006): $776-783$.

Holton, Richard. "How Is Strength of Will Possible?" In Weakness of Will and Practical Irrationality, ed. by Sarah Stroud and Christine Tappolet, 39-67. Oxford: Oxford University Press, 2003.

ㄴ.m. "Intention and Weakness of Will." Journal of Philosophy 96 (1999): 241262.

Hursthouse, Rosalind. On Virtue Ethics. Oxford: Oxford University Press, 1999.

Hutchins, Edwin. Cognition in the Wild. Cambridge, Mass.: MIT Press, 1995.

James, William. Principles of Psychology. New York: Holt, 1890.

Jaspers, Karl. General Psychopathology. Baltimore: John Hopkins University Press, 1997.

Johansen, Leif. Lectures on Macroeconomic Planning. Amsterdam: North-Holland, 1977.

Johnson, Robert. "Virtue and Right." Ethics 113 (2003): 810-834.

Johnston, Mark. "Human Concerns without Superlative Selves." In Reading Parfit, edited by Jonathan Dancy, 149-179. Oxford: Blackwell, 1997.

Kachgal, Mera M., L. Sunny Hansen, and Kevin J. Nutter. "Academic Procrastination Prevention/Intervention: Strategies and Recommendations." Journal of Developmental Education 25 (2001): 14-25.

Kahneman, Daniel, and Amos Tversky. "Prospect Theory." Econometrica 47 (1979): 263-91.

Kant, Immanuel. Anthropology from a Pragmatic Point of View. Trans. by Victor Lyle Dowdell. Carbondale, 111.: Southern Illinois University Press, 1978.

The Metaphysics of Morals. Trans. by Mary Gregor: Cambridge: Cambridge University Press, 1996.

- Religion within the Boundaries of Mere Reason. In Religion within the Boundaries of Mere Reason and Other Writings, ed. by Allen Wood and George di Giovanni, 33-191. Cambridge: Cambridge University Press, 1998. 
Katyal, Neal Kumar. "Conspiracy Theory." Yale Law Joumal 112 (2003): 1307 1398.

Kenny, Anthony. The Metaphysics of Mind. New York: Oxford University Press, 1992.

Kim, Jeong-Yoon. "Hyperbolic Discounting and the Repeated Self-Control Problem." Journal of Economic Psychology 27 (2006): 344-359.

Kind, Amy. "The Metaphysics of Personal Identity and Our Special Concern for the Future." Metaphilosophy 35 (2004): 536-553.

Kirby, Kris N. "Bidding on the Future: Evidence against Normative Discounting of Delayed Rewards." Joumal of Experimental Psychology: General 126 (1997): $54-70$.

Kirby, Kris N., and Barbarose Guastello. "Making Choices in Anticipation of Similar Future Choices Can Increase Self-Control." Joumal of Experimental Psychology: Applied 7 (2001): 154-164.

Knaus, William. "Procrastination, Blame, and Change." In Procrastination: Current Issues and New Directions, ed. by Joseph R. Ferrari and Timothy A. Pychyl, 153-166. Corte Madera, Calif: Select, 2000.

Koons, Judith. "Gunsmoke and Legal Mirrors: Women Surviving Intimate Battery and Legal Doctrines." Journal of Law and Policy 14 (2006): 617 693.

Korsgaard, Christine. "The Normativity of Instrumental Reason." In Ethics and Practical Reason, ed. by Garrett Cullity and Berys Gaut, 215-254. Oxford: Oxford University Press, 1997.

Kruglanski, Arie, and Donna Webster. "Motivated Closing of the Mind: 'Seizing' and 'Freezing.'" Joumal of Personality and Social Psychology 103 (1996): 263-283.

Kuhl, Julius. "A Functional-Design Approach to Motivation and Self-Regulation." In Handbook of Self-Regulation, ed. by Monique Boekaert, Paul Pintrich, and Moshe Zeidner, 111-169. San Diego, Calif: Academic Press, 2001.

Laibson, David. "A Cue-Theory of Consumption." Quarterly Journal of Economics 66 (2001): 81-120.

- "Golden Eggs and Hyperbolic Discounting." Quarterly Journal of Economics 62 (1997): 443-477.

- "Life-Cycle Consumption and Hyperbolic Discount Functions." European Economic Review 42 (1998): 861-871.

Laibson, David, Andrea Repetto, and Jeremy Tobacman. "Self-Control and Saving for Retirement." Brookings Papers on Economic Activity 1 (1998): 91-196.

Lay, Clarry H. "Trait Procrastination, Agitation, Dejection, and Self-Discrepancy." In Procrastination and Task Avoidance: Theory, Research, and Treatment, ed. by Joseph R. Ferrari, Judith L. Johnson, and William G. McCown, 97-112. New York: Springer, 1995.

Lay, Clarry H., and Rosemarie Brokenshire. "Conscientiousness, Procrastination, and Person-Task Characteristics in Job Searching by Unemployed Adults." Current Psychology 16 (1997): 83-96.

Lay, Clarry H., and Stuart Silverman. "Trait Procrastination, Anxiety, and Dilatory Behavior." Personality and Individual Differences 21 (1996): 61-67.

Lazarus, Arnold. "Phobias: Broad-Spectrum Behavioral Views." Seminars in Psychiatry 4 (1972): 85-90.

Lea, Stephen E. G., and Paul Webley. "Money as Tool, Money as Drug: The Biological Psychology of a Strong Incentive." Behavioral and Brain Sciences 29 (2006): $161-209$ 
LeDoux, Joseph. The Emotional Brain. New York: Simon \& Schuster, 1996.

Lengfelder, Angelika, and Peter M. Gollwitzer. "Reflective and Reflexive Action Control in Patients with Frontal Brain Lesions." Neuropsychology 15 (2001): $80-100$.

Levy, Neil. "Self-Deception and Responsibility for Addiction." Journal of Applied. Philosophy 20 (2003): 133-142.

Levy, R. A. "Failure to Refill Prescriptions: Incidence, Reasons and Remedies." In. Patient Compliance in Medical Practice and Clintical Trials, ed. by Joyce Cramer and Bert Spilker, 11-18. New York: Raven, 1991.

Lively, Lynn. The Procrastinator's Guide to Success. London: McGraw-Hill, 1999.

Loewenstein, George. "Out of Control: Visceral Influences on Behavior." Organizational Behavior and Human Decision Processes 65 (1996): 272-292.

- "A Visceral Account of Addiction." In Getting Hooked: Rationality and Addiction, ed. by Jon Elster and Ole-Jørgen Skog, 235-264. Cambridge: Cambridge University Press, 1999.

Loewenstein, George, and Richard H. Thaler: "Anomalies: Intertemporal Choice." Joumal of Economic Perspectives 3, no. 4 (1989): 189-193.

Lynn, Steven J., and Judith W. Rhue. "Tantasy Proneness: Hypnosis, Developmental Antecedents, and Psychopathology." American Psychologist 43 (1988): $35-44$.

MacIntosh, Duncan. "Buridan and the Circumstances of Justice (On the Implications of the Rational Unsolvability of Certain Co-ordination Problems). "Pacific Philosophical Quarterly 73 (1992): 150-173.

m. "Prudence and the Reasons of Rational Persons." Australasian Joumal of Philosophy 79 (2001): 346-365.

Mahoney, Martha R. "Legal Images of Battered Women: Redefining the Issue of Separation." Michigan Law Review 90 (1991): 1-71.

Marcus, Gary. Kluge: The Haphazard Construction of the Human Mind. London: Faber and Faber, 2008.

Maunsell, John H. R. "Neuronal Representations of Cognitive State: Reward or Attention?" Trends in Cognitive Sciences 8 (2004): 261-265.

Maxwell, Bruce. Professional Ethics Education: Studies in Compassionate Empathy. Dordrecht: Springer, 2008.

Mazur, James E. "An Adjusting Procedure for Studying Delayed Reinforcement." In Quantitative Analysis of Behavior Vol. 5: The Effect of Delay and of Intervening Events on Reinforcement Value, ed. by Michael Commons, James Mazur, John Nevin, and Howard Rachlin, 55-73. Hillsdale, N.J.: Lawrence Erlbaum, 1987.

- "Hyperbolic Value Addition and General Models of Animal Choice." Psychological Review 108 (2001): 96-112.

- "Procrastination by Pigeons: Preference for Larger, More Delayed Work Requirements." Journal of the Experimental Analysis of Behavior 65 (1996): 159-171.

__ "Procrastination by Pigeons with Fixed-Interval Response Requirements." Joumal of the Experimental Analysis of Behavior 69 (1998): 185-197.

McClennen, Edward E. "Pragmatic Rationality and Rules." Philosophy and Public Affairs 26 (1997): 210-258.

Rationality and Dynamic Choices: Foundational Explanations. Cambridge: Cambridge University Press, 1990. 
McClure, Samuel, David Laibson, George Loewenstein, and Jonathan Cohen. "Separate Neural Systems Value Immediate and Delayed Monetary Rewards." Science 306 (2004): 503-507.

McDowell, John. Mind, Value, and Reality. Cambridge, Mass.: Harvard University Press, 1998.

- . "Reductionism and the First Person." In Reading Parfit, ed. by Jonathan Dancy, 230 250. Oxford: Blackwell, 1997.

McIntyre, Alison. "Is Akratic Action Always Irrational?" In Identity, Character, and Morality: Essays in Moral Psychology, ed. by Owen Flanagan and Amélie Oksenberg Rorty, 379-400. Cambridge, Mass.: MIT Press, 1993.

. "What Is Wrong with Weakness of Will?" Journal of Philosophy 103 (2006): 284-311.

Mele, Alfred. Irrationality: An Essay on Akrasia, Self-Deception and Self.Control. New York: Oxford University Press, 1987.

Metcalfe, James, and Walter Mischel. "A Hot/Cool-System Analysis of Delay of Gratification: Dynamics of Willpower." Psychological Review 106 (1999): 3-19.

Millgram, Elijah. Ethics Done Right: Practical Reasoning as a Foundation for Moral Theory. Cambridge: Cambridge University Press, 2005.

- Practical Induction. Cambridge, Mass.: Harvard University Press, 1997.

- "Williams' Argument against External Reasons." Nous 30 (1996): 197-220.

Milne, Sarah, Sheina Orbell, and Paschal Sheeran. "Combining Motivational and Volitional Interventions to Promote Exercise Participation: Protection Motivation Theory and Implementation Intentions." British Journal of Health Psychol. ogy 7 (2002): 163-184.

Mirrlees, James A. "The Optimal Structure of Incentives and Authority within an Organization." Bell Joumal of Economics 7 (1976): 105-131.

Monterosso, John, and George Ainslie. "Beyond Discounting: Possible Experimental Models of Impulse Control." Psychopharmacology 146 (1999): 339-347.

Monterosso, John, George Ainslie, Pamela Toppi-Mullen, and Barbara Gault. "The Fragility of Cooperation: A False Feedback Study of a Sequential Iterated Prisoner's Dilemma." Journal of Economic Psychology 23 (2002): 437-448.

Moon, Simon M., and Alfred J. Illingworth. "Exploring the Dynamic Nature of Procrastination: A Latent Growth Curve Analysis of Academic Procrastination." Personality and Individual Differences 38 (2005): 297-309.

Moore, G. E. Principia Ethica. Amherst, Mass.: Prometheus, 1988.

Muraven, Mark, and Roy F. Baumeister. "Self-Regulation and Depletion of Limited Resources: Does Self-Control Resemble a Muscle?" Psychological Bulletin 126 (2000): 247-259.

Muraven, Mark, Roy. F. Baumeister, and Dianne M. Tice. "Longitudinal Improvement of Self-Regulation through Practice: Building Self-Control Strength through Repeated Exercise." Journal of Social Psychology 139 (1999): 446-457.

Muraven, Mark, and Dikla Shmueli. "The Self-Control Costs of Fighting the Temptation to Drink." Psychology of Addictive Behaviors 20 (2006): 154-160.

Muraven, Mark, Dikla Shmueli, and Edward Burkley. "Conserving Self-Control Strength." Journal of Personality and Social Psychology 91 (2006): 524-537.

Murray, E. J., and F. Foote. "The Origins of Fear of Snakes." Behavior Research and Therapy 17 (1979): $489-493$.

Myerson, Joel, and Leonard Green. "Discounting of Delayed Rewards: Models of Individual Choice." Joumal of the Experimental Analysis of Behavior 64 (1995): $263-276$. 
Neurath, Otto. "Die Verirten des Cartesius und das Auxiliarmotiv (Zur Psychologie des Entschlusses)." Jahrbuch der Philosophischen Gesellschafi an der Universität zu Wien (1913): 45-59.

Nichols, Shaun. Sentimental Rules: On the Natural Foundations of Moral Judgment. Oxford: Oxford University Press, 2004.

Norman, Donald A. Things That Make Us Smart: Defending Human Attributes in the Age of the Machine. New York: Basic Books, 1993.

Nussbaum, Martha. Hiding from Humanity: Disgust, Shame, and the Law. Princeton, N.J.: Princeton University Press, 2004.

O'Doherty, John P. "Reward Representations and Reward-Related Learning in the Human Brain: Insights from Neuroimaging." Current Opinion in Neurobiology 14 (2004): 769-776.

O'Donoghue, Ted, and Matthew Rabin. "Doing It Now or Later." American Economic Review, 89 (1999): 103-124.

- "Choice and Procrastination." Quarterly Joumal of Economics 116 (2001): $121-160$.

. "Incentives for Procrastinators." Quarterly Journal of Economics 114 (1999): $769-816$.

- "Procrastination in Preparing for Retirement." In Behavioral Dimensions of Retirement Economics, ed. by Henry Aaron, 125-156. Washington, D.C.: Brookings Institute and Russell Sage Foundation, 1999.

. "Procrastination on Long-Term Projects." Journal of Economic Behaviour and Organization 66 (2008): 161-175.

Oettingen, Gabriele, and Peter M. Gollwitzer. "Goal Setting and Goal Striving." In Intraindividual Processes, Volume I of the Blackwell Handbook in Social Psychology, ed. by Abraham Tesser and Norbert Schwarz, 329-347. Oxford: Blackwell, 2001.

Oettingen, Gabriele, Gaby Hönig, and Peter M. Gollwitzer. "Effective SelfRegulation of Goal Attainment." International Journal of Educational Research 33 (2000): 705-732.

Owens, Shane G., Christine G. Bowman, and Charles A. Dill. "Overcoming Procrastination: The Effect of Implementation Intentions." Journal of Applied Social Psychology 38 (2008): 366-384.

Pap, Arthur. 1961. "Determinism, Freedom, Moral Responsibility, and Causal Talk." In Determinism and. Freedom in the Age of Modern Science, ed. by Sidney Hook, 200-205. New York: Collier, 1961.

Parfit, Derek. "Personal Identity and Rationality." Synthese 53 (1982): 227-241.

- Reasons and Persons. Oxford: Clarendon Press, 1984.

Patterson, Charlotte J, and Walter Mischel. "Effects of Temptation-Inhibiting and Task-Facilitating Plans of Self-Control." Joumal of Personality and Social. Psychology 33 (1976): 209-217.

Perry, John. "The Importance of Being Identical." In The Identities of Persons, ed. by Amélie Oksenberg Rorty, 67-90. Berkeley: University of California Press, 1976.

- "Structured Procrastination." Available at http://www.structuredprocras tination.com (accessed February 28, 2009).

Pettit, Philip. "Preferences, Deliberation and Satisfaction." In Preferences and Well-Being, ed by Serena Olsaretti, 131-154. Cambridge: Cambridge University Press, 2006.

Phelps, Edmund, and Robert Pollack. "On Second-Best National Saving and Game Equilibrium Growth." Review of Economic Studies 35 (1968): 201-208. 
Posner, Richard A. Economic Analysis of Law, 6th ed. New York: Aspen, 2003.

Powers, Theodor A., Richard Koestner, and Raluca A. Topciu. "Implementation Intentions, Perfectionism, and Goal Progress: Perhaps the Road to Hell Is Paved with Good Intentions." Personality and Social Psychology Bulletin 31 (2005): 902-912.

Powers, Theodor A., David C. Zuroff, and Raluca A. Topciu. "Covert and Overt Expressions of Self-Criticism and Perfectionism and Their Relation to Depression." European Journal of Personality 18 (2004): 61-72.

Prelec, Drazen, and Ronit Bodner. "Self-Signaling and Self-Control." In Time and Decision, ed. by George Loewenstein, Daniel Read, and Roy Baumeister, 277 298. New York: Russell Sage Foundation, 2003.

Putnam, Hilary. "The Meaning of 'Meaning." In Mind, Language and Reality, 215271. Cambridge: Cambridge University Press, 1975.

Pychyl, Timothy A., Richard W. Morin, and Brian R. Salmon. "Procrastination and the Planning Fallacy: An Examination of the Study Habits of University Students." Journal of Social Behavior and Personality 15 (2000): 135m152.

Quinn, Warren. "The Puzzle of the Self-Torturer." In Morality and Action, 198209. Cambridge: Cambridge University Press, 1994.

Rachlin, Howard. The Science of Self-Control. Cambridge, Mass: Harvard University Press, 2000.

Rand, Ayn. "What Is Capitalism?" In Capitalism: The Unknown Ideal, 11-31. New York: Penguin, 1967.

Read, Daniel. "Is Time-Discounting Hyperbolic or Subadditive?" Joumal of Risk and Uncertainty 23 (2001): 5-32.

Rocochnick, David. "Aristotle's Account of the Vicious: A Forgivable Inconsistency." History of Philosophy Quarterly 24 (2007): 207-220.

Ross, Don. Economic Theory and Cognitive Science: Microexplanation. Cambridge, Mass.: MIT Press, 2005.

- "Integrating the Dynamics of Multi-Scale Economic Agency." In The Oxford Handbook of Philosophy of Economics, ed. by Harold Kincaid and Don Ross, 245-279. Oxford: Oxford University Press, 2009.

-. "Introduction: Science Catches the Will." In Distributed Cognition and the Will: Individual Volition and Social Context, ed. by Don Ross, David Spurrett, Harold Kincaid, and G. Lynn Stephens, 1-16. Cambridge, Mass.: MIT Press, 2007.

Ross, Don, David Spurrett, Harold Kincaid, and G. Lynn Stephens, eds. Distributed Cognition and the Will: Individual Cognition and Social Context. Cambridge, Mass.: MIT Press, 2007.

Ross, Stephen. "The Economic Theory of Agency: The Principal's Problem." American Economic Review 63, no. 2 (1973): 134-139.

Ryle, Gilbert. The Concept of Mind. Chicago: University of Chicago Press, $1949 / 1984$.

Sanchirico, Chris William. "Detection Avoidance." New York University Law Review 81 (2006): 1331-1391.

Sanders, Teela. "Becoming an Ex-Sex. Worker: Making Transitions Out of a Deviant Career." Feminist Criminology 2 (2007): 74-95.

Sani, Fabio. "Introduction and Overview." In Self-Continuity: Individual and Collective Perspectives, ed, by Fabio Sani, 1-19. New York: CRC Press/Taylor and Francis Group, 2008.

Scanlon, T. M. What We Owe to Each Other. Cambridge, Mass: Belknap, 1998. 
Schelling, Thomas. "Economics, or the Art of Self-Management." American Economic Review 68, no. 2 (1978): 290-294.

- "The Intimate Contest for Self-Command." Public Interest 60 (1980): 94-118. "Self-Command in Practice, in Policy, and in a Theory of Rational Choice." American Economic Reniew 74, no. 2 (1984): 1-11.

Schouwenburg, Henri C. "Academic Procrastination: Theoretical Notions, Measurement, and Research." In Procrastination and Task Avoidance: Theory, Research, and Treatment, by Joseph R. Ferrari, Judith L. Johnson, and William G. McCown, 71-96. New York: Springer, 1995.

"Procrastination in Academic Settings: General Introduction." In Counseling the Procrastinator in Academic Settings, ed. by Henri C. Schouwenburg, Clarry Lay, Timothy A. Pychyl, and Joseph Ferrari, 3-17. Washington, D.C.: American Psychological Association, 2004.

Schouwenburg, Henri C., and Jan T. Groenewoud. 2001. "Study Motivation under Social Temptation: Effects of Trait Procrastination." Personality and Individual Differences 30: 229-240.

Schouwenburg, Henri C., Clarry H. Lay, Timothy A. Pychyl, and Joseph R. Ferrari. Counseling the Procrastinator in Academic Settings. Washington, D.C.: American Psychological Association, 2004.

Searle, John. Rationality in Action. Cambridge, Mass: MIT Press, 2001.

Seidler, Michael. "Kant and the Stoics on the Emotional Life." Philosophy Research Archives 7 (1981): 1-56.

Seneca. "On Anger." In Seneca: Moral and Political Essays, ed. by John M. Cooper and J. F. Procopé, 1-116. Cambridge: Cambridge University Press, 1995.

Shafir, Eldar, Itamar Simonson, and Amos Tversky. "Reason-Based Choice," Cognition 49 (1993): 11-36.

Shah, James Y., Rose Friedman, and Arie W. Kruglanski. "Forgetting All Else: On the Antecedents and Consequences of Goal Shielding." Joumal of Personality and Social Psychology 83 (2002): 1261-1280.

Sheeran, Paschal. "Intention-Behavior Relations: A Conceptual and Empirical Review." European Review of Social Psychology 12 (2002): 1-36.

Sheeran, Paschal, Thomas L. Webb, and Peter M. Gollwitzer. "The Interplay between Goal Intentions and Implementation Intentions." Personality and Social Psychology Bulletin 31 (2005): 87-98.

Shoemaker, David W. "Caring, Identification, and Agency." Ethics 114 (2003): 88-118.

"Personal Identity and Ethics." In Stanford Encyclopedia of Philosophy, ed. by Edward N. Zalta. Available at http://platostanford.edu/entries/identityethics/ (accessed February 28, 2009).

- "Personal Identity and Practical Concerns." Mind 116 (2007): 316-357.

Shoemaker, Sydney. "Comments." In Perception and Personal Identity: Proceedings of the 1967 Oberlin Colloquium in Philosophy, ed. by Norma Care and Robert Grimm, 107-127. Cleveland: The Press of Case Western Reserve University, 1969.

Shope, Robert. "The Conditional Fallacy in Contemporary Philosophy." Journal of Philosophy 75 (1978): 397-413.

Sidgwick, Henry. The Methods of Ethics, 7th ed. London: Macmillan, 1907.

Sigall, Hal, Arie Kruglanski, and Jack Fyock. "Wishful Thinking and Procrastination." Joumal of Social Behavior and Personality 15 (2000): 283-296. 
Silver, Maury, and John Sabini. "Procrastinating." Journal for the Theory of Social Behavior 11 (1981): 207-221.

Sjoberg, Lennart, and Tommy Johnson. "Trying to Give Up Smoking: A Study of Volitional Breakdowns." Addictive Behaviors 3 (1978): 149-164.

Skog, Ole-Jørgen. "Hyperbolic Discounting, Willpower, and Addiction." In Addiction: Entries and Exits, ed. by Jon Elster, 151-168. New York: Russell Sage Foundation, 1999.

Smart, R. G. "Spontaneous Recovery in Alcoholics: A Review and Analysis of the Available Research." Drug and Alcohol Dependence 1 (1975): 277-285.

Solomon, L. J., and E. D. Rothblum. "Academic Procrastination: Frequency and Cognitive-Behavioral Correlates." Journal of Counseling Psychology 31 (1984): 503-509.

Sorenson, Roy. "Originless Sin: Rational Dilemmas for Satisficers." Philosophical Quarterly 56 (2006): 213-223.

Spellecy, Ryan. "Reviving Ulysses Contracts." Kennedy Institute of Ethics Journal 13 (2003): 373-392.

Sreenivasan, Gopal. "Errors about Errors: Virtue Theory and Trait Attribution." Mind 111 (2002): 48-68.

Stadler, Gertraud, Gabriele Oettingen, and Peter M. Gollwitzer. "Effects of a Self-Regulation Intervention on Women's Physical Activity." American Joumal of Preventive Medicine 36 (2009): 29-34.

Steel, Piers. "Case Studies." Available at http://www.procrastinus.com (accessed February 28, 2009).

- "The Nature of Procrastination: A Meta-Analytic and Theoretical Review of Quintessential Self-Regulatory Failure." Psychological Bulletin 133 (2007): $65-94$.

Steel, Piers, Thomas Brothen, and Catherine Wambach. "Procrastination and Personality, Performance, and Mood." Personality and Individual Differences 30 (2001): $95-106$.

Strotz, Robert. "Myopia and Inconsistency in Dynamic Utility Maximization." Review of Economic Studies 23 (1956): 165-180.

Stroud, Sarah. "Weakness of Will." In Stanford Encyclopedia of Philosophy, ed. by Edward N. Zalta. Available at http:/plato.stanford edu/entries/weakness-will/ (accessed February 28, 2009).

Stroud, Sarah, and Christine Tappolet. "Introduction." In Weakness of Will and Practical Irrationality, ed. by Sarah Stroud and Christine Tappolet, 1-16. Oxford: Oxford University Press, 2003.

Sully, James. Outlines of Psychology. New York: Appleton, 1884.

Tenenbaum, Sergio. "Intention and Commitment." Working paper.

-2. "Speculative Mistakes and Ordinary Temptations: Kant on Instrumental Conceptions of Rationality." History of Philosophy Quarterly 20 (2003): $203-223$.

Thaler, Richard H. "Mental Accounting and Consumer Choice." Marketing Science 4 (1985): 199-214.

. "Saving, Fungibility and Mental Accounts." Journal of Economic Perspectives 4 (1990): 193-205.

Thaler, Richard H., and Cass Sunstein. Nudge: Improving Decisions about Health, Wealth and Happiness. New Haven: Yale University Press, 2008.

Thompson, Michael Life and Action. Cambridge, Mass.: Harvard University Press, 2008. 
Tice, Dianne M., and Roy F. Baumeister. "Longitudinal Study of Procrastination, Performance, Stress and Health: The Costs and Benefits of Dawdling." Psychological Science 8 (1997): 454-458.

Trope, Yaacov, and Nira Libennan. "Temporal Construal and Time-Dependent Changes in Preference." Joumal of Personality and Social Psychology 79 (2000): $876-889$.

Utset, Manuel A. "Hyperbolic Criminals and Repeated Time-Inconsistent Misconduct." Houston Law Review 44 (2008): 609 677.

Van Eerde, Wendelien. "A Meta-Analytically Derived Nomological Network of Procrastination.." Personality and Individual Differences 35 (2003): 1401-1418.

- "Procrastination: Self-Regulation in Initiating Aversive Goals." Applied Psychology 49 (2000): 372-389.

Velleman, J. David. The Possibility of Practical Reason. Oxford: Clarendon Press, 2000.

"What Happens When Someone Acts?" Mind 101 (1992): 461-481.

Verplanken, Bas, and Suzanne Faes. "Good Intentions, Bad Habits, and Effects of Forming Implementation Intentions on Healthy Eating." European Journal of Social Psychology 29 (1999): 591-604.

Vogler, Candace. "Anscombe on Practical Inference." In Varieties of Practical Reasoning, ed. by Elijah Millgram, 437-464. Cambridge, Mass.: MIT Press, 2001.

Reasonably Vicious. Cambridge, Mass.: Harvard University Press, 2002.

Vohs, Kathleen D., Roy F. Baumeister, Brandon J. Schmeichel, Jean M. Twenge, Noelle M. Nelson, and Dianne M. Tice. "Making Choices Impairs Subsequent Self-Control: A Limited-Resource Account of Decision Making, Self-Regulation, and Active Initiative." Journal of Personality and Social Psychology 94 (2008): 833 898 .

Vygotsky, Lev S. Thought and Language, rev. ed. Cambridge, Mass.: MIr Press, 1986.

Wallace, R. Jay. Normativity and the Will: Selected Essays on Moral Psychology and Practical Reason. Oxford: Oxford University Press, 2006.

Webb, Thomas L., Julie Christian, and Christopher J. Armitage. "Helping Students Turn Up for Class: Does Personality Moderate the Effectiveness of an Implementation Intention Intervention?" Learning and Individual Differences 17 (2007): $316-327$.

Webb, Thomas L., and Paschal Sheeran. "Can Implementation Intentions Help to Overcome Ego-Depletion?" Joumal of Experimental Social Psychology 39 (2003): 279-286.

- "Does Changing Behavioral Intentions Engender Behavior Change? A Meta-Analysis of the Experimental Evidence." Psychological Bulletin 132 (2006): 249-268.

"Mechanisms of Implementation Intention Effects: The Role of Goal Intentions, Self-Efficacy, and Accessibility of Plan Components." British Journal of Social Psychology 47 (2008): 373-395.

Weber, Max. The Protestant Ethic and the Spirit of Capitalism. New York: Charles Scribner's Sons, 1958.

Wegner, Daniel M. The Illusion of Conscious Will. Cambridge, Mass: MIT Press, 2002.

White Bears and Other Unwanted Thoughts: Suppression, Obsession, and the Psychology of Mental Control. New York: Penguin, 1989. 
Weinberger, Jerry. Ben Franklin Unmasked: On the Unity of His Moral, Religious, and Political Thought. Lawrence: Kansas University Press, 2008.

Wertsch, James V. Mind as Action. New York: Oxford University Press, 1998.

White, Mark D. "Behavioral Law and Economics: The Assault on Consent, Will, and Dignity." In New Essays on Philosophy, Politics \&: Economics: Integration and Common Research Projects, ed. by Gerald Gaus, Christi Favor, and Julian Lamont. Stanford, Calif.: Stanford University Press, forthcoming.

- "Can Homo Economicus Follow Kant's Categorical Imperative?" Joumal of Socio-Economics 33 (2004): 89-106.

- "Does Homo Economicus Have a Will?" In Economics and the Mind, ed. by Barbara Montero and Mark D. White, 143-158. London: Routledge, 2007.

- "Multiple Selves and Weakness of Will: A Kantian Perspective." Review of Social Economy 64 (2006): 1-20.

Whiting, Jennifer. "Friends and Future Selves." Philosophical Review 95 (1986): $547-580$.

Wieber, Frank, Georg Odenthal, and Peter M. Gollwitzer. "Self-Efficacy Feelings Moderate Implementation Intention Effects." Self and Identity, forthcoming.

Wieber, Frank, and Kai Sassenberg. "I Can't Take My Eyes Off of It: Attention

Attraction Effects of Implementation Intentions." Social Cognition 24 (2006): $723-752$.

Wieber, Frank, Antje von Suchodoletz, Tobias Heikamp, Gisela Trommsdorff, and

Peter M. Gollwitzer. "Implementation Intentions Improve Resistance to Temptation in Young Children." Working paper.

Williams, Bernard. Ethics and the Limits of Philosophy. Cambridge, Mass.: Harvard University Press, 1985.

- "Internal and External Reasons." In Moral Luck, 101-113. Cambridge: Cambridge University Press, 1982.

- "Persons, Character and Morality." In Moral Luck, 1-19. Cambridge: Cambridge University Press, 1982.

- "Replies." In World, Mind and Ethics: Essays on the Ethical Philosophy of Bernard Williams, ed. by J. E. J. Altham and Ross Harrison, 185-224. Cambridge: Cambridge University Press, 1995.

Winter, Sidney. "Economic 'Natural Selection' and the Theory of the Firm." Yale Economic Essays 4 (1964), 225-272.

Wolf, Susan. "The Meanings of Lives." In Introduction to Philosophy: Classical and Contemporary Readings, 4th ed., edited by John Perry, Michael Bratman, and John Martin Fischer, 62-73. New York: Oxford University Press, 2006.

- "Self-Interest and Interest in Selves." Ethics 96 (1986): 704-720.

Wray, Ian, and Mark G. Dickerson. "Cessation of High Frequency Gambling and 'Withdrawal' Symptoms." British Joumal of Addiction 76 (1981): 401-405.

Zauberman, Gal, and John G. Lynch. "Resource Slack and Discounting of Future Time versus Money." Joumal of Experimental Psychology: General 134 (2005): $23-37$.

Ziesat, Harold A., Jr, Ted L. Rosenthal, and Glenn M. White. "Behavioral Self-Control in Treating Procrastination of Studying." Psychological Reports 42 (1978): 59-69. 